\title{
Capital Markets, Infrastructure Investment and Growth in the Asia Pacific Region
}

\author{
Michael Regan \\ Faculty of Society and Design, Bond University, Gold Coast QLD 4229, Australia; \\ mregan@bond.edu.au; Tel.: +61-7-55952283
}

Academic Editors: Katsuhiko Takagaki and Nicholas Apergis Received: 14 July 2016; Accepted: 5 January 2017; Published: 9 February 2017

\begin{abstract}
This paper examines the relationship between infrastructure investment activity, capital market development, the role of public institutions and economic development in the Asia Pacific. It adopts a review approach drawing on empirical evidence over recent decades. Infrastructure is shown to be an important asset class playing a central role in a nation's output, growth, productivity and microeconomic performance. Infrastructure investment also requires investment and predictions of a widening gap in the future supply of infrastructure in the Asia Pacific will require new forms of capital from both traditional and new sources including wider use of private participation, institutional investment, asset recycling and revenue bonds. Capital market development is also necessary to raise long-term local currency finance and evidence suggests that progress with regional capital market integration is slow and a continuing reform agenda is required. The dividend for regional countries is the prospect of higher levels of economic growth with infrastructure investment, capital market development, and foreign direct investment shown to have a strong and positive association with growth. A crucial link in this association identified in the review is the part played by national and regional institutions in improving the efficiency with which infrastructure is managed and providing promising ground for further research where the importance of these links can be researched in greater depth.
\end{abstract}

Keywords: infrastructure; capital markets; economic growth

JEL Classification: E44; H54; O43

\section{Introduction}

Rutherford [1] describes infrastructure as the networks, assets and services that facilitate economic and social activity in the economy. In economic terms, infrastructure refers to fixed and durable assets such as plant, equipment, buildings and civil works that provide the productive framework of an economy. Economic infrastructure is major asset class in most countries and possesses a number of unique investment and financing characteristics:

- Assets are long lived, capital-intensive, site and use specific

- Assets form part of complex supply chains and in the energy, transport and telecommunications sectors, attract a high level of private sector participation

- Revenue is generally stable, indexed and in the utilities sector, demand is generally characterised by low elasticity

- Private investment is highly leveraged with long-term, limited-recourse loans or bonds

- Projects may be subject to limited competition but pricing is regulated, Regan [2].

Public infrastructure generates a number of positive externalities that increase a country's productive capacity, output and growth. It accounts for a significant proportion of the nation's capital 
stock with implications for capital deepening, productivity performance, greater diversification in trade and reduced transaction costs. Infrastructure output and pricing is an input for most other sectors of the economy with consequential impacts for the cost structures of other industries and the efficiency of cross-sector supply chains. Studies suggest that infrastructure makes a significant contribution to a country's gross value added, growth and gross operating surplus, Deole and Gallaa [3]; Pereira and Andraz [4]. As an asset class, infrastructure returns disclose a low correlation with other asset classes and leading economic variables such as interest rates, investment, employment, economic growth and exchange rate indicators, Weber and Alfen [5], and offers an opportunity for diversification in mixed asset portfolios, Peng and Newell [6]. Infrastructure improves connectivity, lowers transaction costs and fosters the development of production networks and cross-border supply chains. Infrastructure has contributed to the region's emergence as the fastest-growing regional economy in the world, Bhattacharyay [7].

In global industrialised economies, infrastructure investment is presently in the range $3.0 \%-3.9 \%$ GDP, McKinsey [8]; Harrison [9], although high capital intensity means that around half of all new investment is accounted for by capital retirements or real depreciation of existing capital stock although this varies with the capital intensity, Berlemann and Wesselhoft [10]; Australian Bureau of Statistics [11]. In recent years, public investment in industrialised economies has increased for social infrastructure assets such as health, education, corrective services and urban transport in the medium to high-income countries, and inter-regional transport, energy, water and destination transport services such as ports and airports in medium income countries. Data for developing countries indicates most public and private investment is concentrated in the energy, resources and transport sectors and exhibits lower average asset age and capital write-downs than for industrialised economies, Mackenzie [12]; Project Finance International [13]. In developing countries, demand drivers include population growth and rapid urbanisation which requires higher levels of infrastructure investment in energy (electricity, oil and gas), roads, ports, rail and urban transport, water and sanitation services, PricewaterhouseCoopers [14]. In the Asia Pacific, public infrastructure investment in the period 2010-2014 was highest in China (22.5\% of gross domestic product or GDP), Malaysia (10.5\%), India (7.5\%), Canada and Australia (6\%), New Zealand (5\%), and Korea (4\%) although recent data indicates regional average investment levels around $8 \%$ of GDP, Ding, Lam and Peiris [15]; Chong and Poole [16]; McKinsey [8].

Infrastructure forms part of complex supply chains and requires long-term planning and financing strategies. In most Asian Pacific countries, the demand for replacement and new infrastructure exceeds the financial capacity of most governments to provide especially in low-income countries with a limited revenue base, high rates of urbanisation and high-levels of congestion in towns and cities. A combination of current account constraints, global borrowing limits and sub-investment grade credit ratings constrain significant new investment in infrastructure services in the foreseeable future, Bhattacharyay [17]. The challenge for Asia Pacific governments is meeting growing demand for services using a combination of traditional and alternative financing methods and providing appropriate intermediation pathways for high domestic savings. McKinsey [8] estimates global infrastructure needs of USD57 trillion between 2013 and 2030, equivalent to around 3\% of gross domestic product (GDP) annually. The greatest requirements are in the sectors of energy, water supplies and transport services including ports, roads and railways. Regional estimates of the infrastructure investment gap suggest the present global funding deficit is around USD800 billion annually, PricewaterhouseCoopers [14].

The objective of this paper is to identify the relationship between capital markets, investment in infrastructure and economic growth in the Asia Pacific region drawing on recent literature on these subjects. The paper is organized as follows. The introduction examines the characteristics of infrastructure as an asset class and Section 2 identifies methods to finance regional infrastructure requirements over the next 20 years. Section 3 reviews the literature that explains the association between infrastructure investment and economic growth. Section 4 considers capital markets in the region and initiatives for capital market development, integration and the standardization of market 
rules. Section 5 examines the relationship between capital market development and economic growth. The conclusion attempts to summarize the findings of each part and identify future directions for this research.

\section{Infrastructure and Its Financing}

In developing and transition economies, government provides around $70 \%$ of infrastructure mostly in the form of public goods, International Monetary Fund (IMF) [18]. Most infrastructure is financed by government which is increasingly difficult to sustain in the medium term with expectations that global economies are expected to converge at an average 3\% GDP in 2020 which is insufficient to make progress with the shortfall in investment that has accrued over the past decade, Standard and Poor's [19]. For developing countries, the problem is exacerbated by changes to prudential rules that are being introduced to the banking system over the period to 2019 (Basel III), Asian Bankers Association [20]. The changes apply new liquidity and capital adequacy requirements that limit the capacity of the banks to provide limited recourse and long-term loans.

The options for government to finance infrastructure investment include the reordering of budget allocations, by privatizing state business enterprises, raising taxes, or with borrowings either directly or through the agency of government business enterprises.

\subsection{Budget Reallocation}

Government may reorder appropriations from the budget and forward estimates to meet the investment needs of the day, Productivity Commission [21]; Chong and Poole [16]. Funding for public works is volatile with frequent cutbacks and delays in funding common, Productivity Commission [21]. There are several causes including mid-cycle mini-budgets, budget review by parliamentary expenditure review committees, pressure from international agencies on fiscal deficits, electoral cycles and change in government. In federal jurisdictions, vertical fiscal imbalance may lead to unsustainable programming of public works with central government budget cutbacks to provincial and municipal governments responsible for most infrastructure delivery.

A short-term approach to funding infrastructure projects and budget reallocation may come at a high price if it impedes long-term planning or is made for political reasons without formal planning and evaluation such as benefit-cost analysis or a business case which are commonly cited as best practice infrastructure procurement, Regan Smith and Love [22]. Budget and economic planning processes, accounting and reporting practices, and governance standards vary between countries although most governments order public spending to a three or five-year plan or set of forward estimates. Budget appropriations are mostly funded from general taxation or public borrowings both of which may attract varying levels of deadweight costs. Reordering budget priorities creates an opportunity cost generally measured using social time preference and social opportunity cost methods requiring comparative analysis of the social return of undertaking one project at the expense of another, Chan et al. [23]. Short-term changes in budgetary settings also contribute to inefficiencies measured at an average $27 \%$ of public capital spending in developing countries, Abiad, Furceri, and Topalova [24].

Reallocation of budgets in developing and emerging economies also creates investment shocks that have been shown to lower capital productivity and efficiency, IMF [18]. Short-term changes to public spending programs have also been shown to increase risk at the project level with the National Audit Office in the United Kingdom adjusting benchmarks to recognize delay and cost increases when project funding is suspended during the implementation phase of long-term projects, National Audit Office [25].

\subsection{Privatization}

A common practice in the 1980s in many Asia-Pacific nations was the sale of stock in existing government business enterprises (GBEs) either by trade sale, or initial public offerings (IPOs) on a securities exchange. The early privatized assets were high-value stand-alone corporations 
with an established trading history that were readily bankable deals attracting wide interest from multinational trading corporations, institutional investors and both domestic and international investors. In many Asia Pacific countries, early GBE disposals included state-owned banks, insurance companies, telecommunication and information service companies, ports and energy generators, Megginson (pp. 14-21, [26]). A second phase of privatizations took place in the 1990's based on trade sales and a small number of IPOs, Reserve Bank of Australia [27]. By 2001, privatizations had raised USD1.5 tn for global governments although through the 2000s, readily saleable assets were becoming much harder to find, Megginson [26].

A third phase of privatization or asset recycling is taking place at the present time whereby government sells assets to meet the cost of new investment or enters into a long-term lease of a mature income-producing infrastructure to finance the construction of new assets. The assets must be financially viable to buyers and may require subsidies or other forms of ongoing support during early years' of operation, Australian Government [28]. Recycled assets include tolled bridges, roads and tunnels, airports, electricity generation and transmission facilities, defence support establishments, ports, and commercial property portfolios. Unlike the enterprise disposals that preceded it, asset recycling offers a sustainable means of raising additional capital for infrastructure reinvestment with full reversion to the state on expiry of the lease. Nevertheless, privatisation as a source of capital is a diminishing option for government particularly in Asia where few viable and attractive public assets remain to be sold.

\subsection{Raising Taxes}

Consolidated revenue provides the basis of most state appropriations to infrastructure spending and may take the form of higher direct and indirect taxes with economy-wide effect, the raising of a tax or levy by sub-national government with limited jurisdiction, and the imposition of local area and user charges. New taxes to finance infrastructure has several disadvantages. First, taxes are costly to collect and administer, and create induced effects such as tax avoidance behaviors. Taxes also bear significant deadweight costs, which in economic terms, may exceed the net proceeds of the measure, Regan [29]. Second, increasing taxes has been shown to have a negative impact on regional savings and economic growth and may distort economic decision-making and create perverse incentives, Chan et al. (p. 53, [23]), although the extent of this depends on the purpose of the tax and whether or not the tax is applied to consumption or income, Helms [30]. Third, the discriminatory taxation of specific communities or users encounters the Pareto optimality problem and a number of equity and welfare distortions, the more important being the affordability of the tax for lower income groups, Regan (pp. 26-27, [29]).

The ratio of taxation to GDP in developed economies in 2015 averaged 0.42 while the Asia Pacific averaged 0.20 of which around $71 \%$ were income taxes, OECD Statistics [31]; Martinez-Vazques [32]. While there are differences between countries, data suggest that low income economies (Myanmar (0.13), Cambodia (0.05), Indonesia (0.15), Thailand (0.17) and the Philippines 0.12) have a lower tax base than the average for higher income countries in the region. Taxation to provide infrastructure investment is neither a feasible or sustainable option for governments with a low tax base or those with constitutional impediments that create vertical fiscal imbalance between the levels of government.

\subsection{Public Debt}

Public debt is a major source of infrastructure investment and may take the form of general-purpose public borrowings, loans under official development agency assistance and the sale of conventional, revenue or tax-advantaged bonds. In the Asia Pacific, the events of 2007-2008 led to an increase in fiscal deficits and public debt between 2006 and 2014. In 2014, the average public debt of many Asia Pacific countries exceeded their 2007-2014 external debt average in GDP terms, International Monetary Fund [33,34]. Regional economies experiencing significant growth in gross public debt included Australia, New Zealand, Japan, China, Malaysia, Korea, Vietnam, Singapore and 
Taiwan, International Monetary Fund [35]. See Table 1. A concurrent problem was growth in budget deficits over this period with implications for sovereign credit ratings over the longer term and the risk of higher interest rates for offshore borrowing. Deficits and public debt may be a limited option for government infrastructure spending over the medium term.

Public debt in Asia Pacific countries makes wide use of local currency bond issues using domestic and regional bond markets which reduces reliance on offshore borrowings and foreign currency exchange risks. The Asian Bond Market continues to grow with a 5\% quarter-on-quarter increase in issues in 2015. Public bonds accounted for $96.7 \%$ of the Asian Bond Market, ADB (p. 5, [36]). In Asia, several nations grant tax exemptions for interest income received by residents with concessional income and withholding taxes applying to corporations and non-resident institutional investors, ADB [37]. The rapid growth of the middle class in Asia over the past 20 years and high domestic savings provide a ready source of capital intermediated through local capital markets.

Table 1. Public Debt, Asia Pacific, 2007-2013.

\begin{tabular}{|c|c|c|c|c|c|c|c|c|}
\hline GDP \% & 2007 & 2008 & 2009 & 2010 & 2011 & 2012 & 2013 & Av. \\
\hline Australia & 4.9 & 4.6 & 2.9 & 3.0 & 4.4 & 3.5 & 3.5 & 3.8 \\
\hline Brunei & 2.1 & 1.5 & 3.0 & 4.6 & 6.5 & 4.5 & 4.9 & 3.9 \\
\hline Cambodia & 1.6 & 1.8 & 0.9 & 2.0 & 2.3 & 2.3 & 2.6 & 1.9 \\
\hline China & 4.8 & 4.1 & 3.3 & 4.5 & 4.4 & 3.5 & 3.7 & 4.0 \\
\hline Hong Kong SAR & 29.4 & 30.6 & 25.4 & 36.2 & 38.7 & 28.5 & 27.9 & 31.0 \\
\hline Indonesia & 1.6 & 1.8 & 0.9 & 2.0 & 2.3 & 2.3 & 2.6 & 1.9 \\
\hline Japan & 0.5 & 0.5 & 0.2 & 0.1 & 0.0 & 0.0 & 0.2 & 0.2 \\
\hline Korea (Rep.) & 0.8 & 1.1 & 1.0 & 0.9 & 0.8 & 0.8 & 1.0 & 0.9 \\
\hline Malaysia & 4.7 & 3.3 & 0.1 & 4.3 & 5.1 & 3.1 & 3.6 & 3.5 \\
\hline Mongolia & 8.8 & 15.0 & 13.6 & 23.5 & 45.3 & 36.2 & 17.1 & 22.8 \\
\hline Myanmar & 0.0 & 0.0 & 0.0 & 0.0 & 0.0 & 1.7 & 3.6 & 0.8 \\
\hline New Zealand & 3.2 & 2.0 & 0.0 & 0.9 & 0.8 & 2.1 & -0.3 & 1.2 \\
\hline Philippines & 2.0 & 0.8 & 1.2 & 0.5 & 0.9 & 1.3 & 1.4 & 1.2 \\
\hline Singapore & 26.5 & 6.3 & 12.4 & 23.3 & 17.4 & 19.5 & 21.4 & 18.1 \\
\hline Taipei & 1.9 & 1.3 & 0.7 & 0.6 & -0.4 & 0.6 & 0.7 & 0.8 \\
\hline Thailand & 4.3 & 2.9 & 1.7 & 2.7 & 0.7 & 3.2 & 3.4 & 2.7 \\
\hline Vietnam & 8.7 & 9.7 & 7.2 & 6.9 & 5.5 & 5.4 & 5.2 & 6.9 \\
\hline
\end{tabular}

Public debt attracts deadweight costs, may crowd out private actors particularly in immature capital markets, and lead to higher interest costs, Agca and Celasun [38]. Public debt also places pressure on sovereign credit ratings, domestic interest rates and may divert investment away from higher-yielding private investment, Regan (pp. 31-32, [29]). While an increase in budget deficits and public debt in Asia Pacific countries is modest compared with other regions, there is a need for regional governments to wind back deficits to longer-term benchmark levels and undertake fiscal consolidation to build greater resilience against the risk of future economic shocks.

\subsection{Tax-Exempt Bonds}

Tax-exempt bonds are interest bearing redeemable securities issued by government for specific national interest projects or general infrastructure purposes, form part of the government's capital budget for infrastructure spending and are accounted as a liability of the government, Ang, Bhansali and Xing [39]; Marlow [40]. Several countries in the region grant tax exemptions on income receipts from all state bond issues including Malaysia and China, ADB [37]. Tax-exempt bonds are attractive to portfolio investors seeking high post-tax returns and high-income jurisdictions but less so in medium and low-income countries with a low tax revenue base. 


\subsection{Revenue Bonds}

An alternative infrastructure financing method is the issue of project-specific revenue bonds to finance new investment in landmark assets such as ports, national highways, electricity generation, water and sewage management, airports and rail transport. Revenue bonds provide finance that is designed to meet project cash flows and frequently use long-dated maturities, interest rates matched to the risk profile of the project and various currency denominations. Revenue bonds may be issued by the project company or government business enterprise on terms that limit bondholder's recourse to the assets and contracts being financed. To enhance the investment attractiveness of revenue bonds, yield may be fixed and supported by government guarantee, a revenue subsidy or a guarantee of redemption. Revenue bonds may be offered in tranches with various maturities, local and foreign currencies, various maturities, and with options to convert to equity at a future date. Revenue bonds have been widely used by private companies to finance infrastructure in the United States, Europe, Canada and Australia. Unlike private firm issues, public revenue bonds may not require independent credit ratings but rely on sovereign ratings held by national and provincial governments and the revenue support options that are put in place by government. Revenue bonds have not been widely used in Asia and account for around 13\% of private capital raisings for infrastructure, Project Finance International (PFI) [13].

\subsection{Private Finance}

The major source of infrastructure capital in the Asia Pacific is project finance arranged by private consortia bidding for greenfield projects in the energy, transport and resources sectors. Private finance is arranged by firms under a wide variety of contracting forms, including public private partnerships (PPPs), build operate transfer (BOT) agreements, and outsourcing and management contracts, Zen and Regan [41]. The region raised US \$260 bn in 2014 and accounted for an average 31\% of global project finance in the 10 years to 2014 with finance provided by international and Asian banks. Finance is raised by project sponsors and will only affect government balance sheets if state obligations are supported by guarantees or indemnities, PFI [13].

\subsubsection{Private Participation in Infrastructure (PPI)}

PPI describes that group of transactions that include divestments or privatization of state-owned agencies, outsourcing arrangements, greenfield investment in new services, and concessions which refers to the build own transfer group of contracts which may be delivered under state procurement policies or as public private partnerships (PPPs) which are delivered under dedicated PPP policies, Zen and Regan [41]. PPI initiatives are designed to attract private investment and management of new infrastructure, generally for terms of 35 years or less, or to outsource the management and manage risks associated with the delivery of state-owned economic and social infrastructure. The economics of PPI have been shown to be underpinned by a strong incentive framework that sustains efficient management over long service intervals, the opportunity for government to transfer most risks associated with construction and operational phases of the project, the capacity of private firms to introduce service delivery and new technologies and to facilitate technology transfer to local sub-contracting firms and their workers. PPI may also attract multilateral financial assistance and contribute to a country's technological capacity. In recent years, PPI programs have been promoted by international agencies as an instrument for the delivery of infrastructure services in developing and transition countries and account for around $7.5 \%$ of infrastructure provision mainly to deliver services in energy, transport and communications, PFI [13].

Private finance increases a nation's pool of capital for infrastructure investment and introduces greater rigor to the procurement and operational stages of the project. A combination of private capital, lender governance, powerful incentives, competitive bidding, risk transfer, innovation and private management efficiency has contributed to improved procurement outcomes. Welfare returns 
can be preserved if the state exercises control over output pricing and service standards. In the past decade, design and construction innovation, technology and efficient management have assumed greater importance in infrastructure procurement with evidence suggesting that PPI is a more efficient option to traditional procurement methods, delivers assets and services at lower cost, and for projects providing social services, results in improved service outcomes, Regan, Love and Smith [22].

Infrastructure achieves higher economic and social returns when it forms part of efficient supply chains in countries with sound public institutions, efficient regulatory policies, sound macroeconomic management, and supporting the enforceability of contracts, fair and competitive bidding practices and alternative dispute resolution procedures. Other important complementarities in the association between infrastructure investment and growth are high external trade, economic openness and liberal foreign direct investment (FDI) regimes, Agenor [42].

\subsubsection{Institutional Investment}

Institutional investment in the forms of equity and debt participation by pension funds, sovereign wealth funds, mutual funds, insurance companies, dedicated infrastructure funds, and portfolio investors has not played a significant role in global infrastructure development. In 2013, the value of institutional funds was estimated by the OECD at US $\$ 92$ tn of which pension funds and insurance companies each accounted for US $\$ 26 \mathrm{tn}$, public pension funds US $\$ 5 \mathrm{tn}$, and other funds US $\$ 7 \mathrm{tn}$. Asian institutional investors account for around US $\$ 12$ tn or $17 \%$ of global funds and while the case for infrastructure as an asset class has been well made out OECD [43]. Asian fund managers have a low exposure to unlisted infrastructure with an average allocation less than $4 \%$ of funds under management although additional allocation may be directed through equity investment in listed stock, Preqin [44]; OECD [45]. Sovereign wealth funds were estimated at US $\$ 6$ tn in 2015, Inderst [46]; Sovereign Wealth Fund Institute [47], of which Asia accounts for US \$2.7 tn Preqin [48]. Infrastructure is one of four asset classes favored by fund managers although the size of investments in both listed and unlisted forms is relatively small with overall asset allocation around $2 \%$ of funds under management, Inderst [46].

Future infrastructure investment by institutional investors may be limited in the medium term with impediments on both the demand and supply sides of the transaction. Unlisted infrastructure is a long-term and illiquid equity investment with low returns in the early stages of the project until revenue builds and the project's unsystematic risk profile diminishes. Infrastructure debt is generally syndicated and limited recourse, which is a problem for managers of trust funds and regulations that cap fund exposure to specific asset classes. Bankable projects are increasingly difficult to finance in networked industries particularly if risk is high and supply chains are subject to high levels of state regulation. These factors are evident in project credit ratings which often fail to achieve credit ratings higher than Standard and Poor's BBB+ in the absence of take or pay contracts, government or multilateral agency credit support, Ehlers, Packer and Remolona [49]. In many mature infrastructure markets such as Britain, Canada, Australia, Europe and the United States, institutional investors hold around $7.5 \%$ of their portfolio in direct and listed equity investments and provide around $2 \%$ of debt financing, Australian Government Future Fund [50]. The evidence suggests that institutional investors will not assume a greater share of the regional infrastructure market in the medium term.

The funding of infrastructure is a continuing challenge for regional governments with demand for economic assets and services exceeding the capacity of government to provide. The support of official development assistance programs, bilateral aid, the financial services provided by multilateral institutions and private participation is partly bridging the supply gap. The limited availability of readily bankable projects has constrained access to project finance for sectors other than the transport, energy and resources sectors. The options for government are partly institutional with capital market development, long-term infrastructure planning and development of a pipeline of appropriate projects for private finance will improve certainty in the market. Other market-driven options include asset recycling, the issue of listed mezzanine and revenue bonds, and the adoption of user pays principles for transport infrastructure including airports, port facilities and motorways. 


\section{Infrastructure Investment and Economic Growth}

Infrastructure has been shown to impact a country's economic performance in a number of ways. Economic infrastructure contributes to an economy's productive capacity and output, Calderon and Serven [51]; Esfahani and Ramirez [52], multifactor productivity and capital deepening, Mas, Maudos, Perez and Uriel [53]; Pereira and Andraz [4], and generates sustainable multipliers of economic activity, Paul [54]. Aghion and Jaravel [55] suggest public infrastructure has a positive effect on GDP that is not restricted to the creation of capital stock via economies of scale but is competition enhancing for the economy through the agency of network externalities. Infrastructure is also linked to lower private transaction costs, Baltagi and Pinnoi [56], adds value to exports, North et al [57]; Barwise and Dick [58], and generates positive social returns, Zhai [59]. Bhattacharyay, (p. 339, [7]) argues that the big factor behind Asia's high growth since that late 1980s was rapid infrastructure development that raised economic efficiency in regional countries, improved connectivity between regional economies and enhanced East Asian production networks and supply chains. Infrastructure affects many different industries and needs are determined by contextual factors such as level of urbanization and structure of the economy and both physical and climatic geography play a significant role with different impacts between countries at various stages of development. Evidence confirms that investment in transport services, energy and telecommunications generate highest returns in developing and transitional economies, Ligthart [60].

The relationship between infrastructure and growth has been difficult to measure with early studies using a static single-equation production function approach showing excessive returns with evidence of diminishing returns, differences in effects between industry sectors and subnational regions over time, and the problem of distinguishing short-term investment multipliers and capital stock accumulation from long-term growth impacts, Regan [61,62]. The interest in the relationship between public investment in infrastructure and economic growth commenced with the early work of Aschaeur [63] who used a production function approach for United States data to identify the elasticity of output for public capital at between 0.34 to 0.39 , implying an annual marginal productivity of public capital of around 70 cents in the dollar. The production function approach encountered reverse causation (simultaneity bias) and led to new approaches based on a multivariate static cost function approach and later, dynamic multivariate vector autoregressive (VAR) settings that took into account private sector employment, investment and output in addition to public capital. Subsequent research used financial and physical measures of infrastructure in both developing and developed economies and used VAR analysis applied to multiple country datasets, Pereira and Andraz [4].

Studies by Warner [64] showed the elasticity of infrastructure investment of 0.11, Everaert and Heylen [65] 0.31 and Kamps [66] 0.22. The relationship with employment was studied by Pereira and Roca-Segales [67] who identified a marginal product of private investment with respect to public investment of 10.2 equating one million Euro with 129 jobs in the long term, Pereira and Roca-Segales [67]. Similar studies based on European data report long-term effects of 8.1 (230 jobs per million Euro of expenditure) and marginal product 9.5 corresponding to a rate of return of $15.9 \%$ per annum, Pereira and Andraz [4].

Esfahani and Ramirez [52] found that the impact of infrastructure investment on growth is substantial when viewed against induced externalities such as the terms of trade, industry structure and specialization, the spatial distribution of industry and the efficiency of investment. Recent research by Ganelli and Tervala [68] adopted a New Keynesian general equilibrium model to show the welfare multipliers of public investment are positive at 0.8 suggesting the welfare gains of public infrastructure investment if implemented efficiently, could be substantial. Egert, Kozluk and Sutherland [69] used time series data for OECD countries to establish a positive causal association between infrastructure investment and growth with the impact greatest for sectors offering economies of scale, network externalities and competition-enhancing effects, with growth effects strongest in the telecommunications and energy sectors of the economy, Esfahani and Ramirez [52]. 
O'Fallon [70] surveyed the empirical evidence to understand the nature of the relationship between infrastructure and growth. She found that a correlation existed but encountered the causation problem common with earlier studies by Aschauer [63] and others. The study suggests infrastructure should be viewed as complimentary assets that operate in concert with other human and/or physical capital to contribute to growth. This is consistent with the contemporary view that infrastructure serves as a catalyst for other growth drivers which include effective institutions and a strong market economy, Egert, Kozluk and Sutherland [71]; Nijkamp and Poot [72]. However, economies and institutions change over time suggesting that the relationship between infrastructure and growth is dynamic and operates in a different way with various levels of development, Regan, Smith and Love [73].

A comprehensive review of the literature examining the economic effects of public infrastructure can be found in Pereira and Andraz [4]. In the Asia Pacific, the relationship between infrastructure and growth has been uneven with considerable differences in levels of market and social development, market structure, urbanisation, incomes and social benefits between regions and countries. Sustained investment in services that improve the productivity of physical and human resources through innovation and technological progress will be primary factors in stimulating growth in any society, Todaro and Smith [74].

Investment in infrastructure is important and so is the efficiency with which it is implemented and managed. As a component of complex supply chains, infrastructure output has important cost implications for other industries in the economy as a proxy for efficiency at the project and enterprise levels. Efficiency is mainly measured as capital and labor productivity and the efficacy of governance and regulatory frameworks. Institutions play a central role in a developing country's economic and social development, and programs to attract private investment in infrastructure are more successful when supported by effective market-oriented institutions, Rodrik and Subramanian [75]. The term institution refers to the formal rules by which a nation manages interaction between individuals and the outside world. Formal institutions are commonly referred to as "the rules of the game" and describe the organizations, policies and administrative frameworks that govern relations between members of society. The institutions that support the market economy include the rule of law, property rights, governance frameworks, an independent judiciary, a central bank, and stable monetary and fiscal policies, Sala-i-Martin et al. [76]. Market institutions and particularly property rights determine the incentives and constraints that influence economic actions and permit the state, firms and individuals to carry out economic activities that generate wealth and allow the market economy to operate with a reasonable level of confidence and certainty, Acemoglu, Johnson and Robinson [77]; North [78].

Property rights in the form of patents and copyright operate to create monopolies for entrepreneurs who invest in research and development, which generally supports high early returns that diminish over time. Recent studies suggest diminishing returns to technology are much greater in our present technology-driven economies than it was in the past. Property rights also create incentives to savings and positive returns to investment and evidence indicates they are a primary driver of savings and capital formation, essential elements of economic development, Baumol, Litan and Schramm [79]. Acemoglu, Aghion and Zilibotti [80] identified the dynamics of this relationship over time as a consequence of the transformation of production relationships, the rate of adoption and imitation of technology, and capacity to manage change. A further factor in the dynamic of this relationship is the level of a nation's economic and social development, Regan, Smith and Love [73].

Institution also refers to the informal cultural and social rules and norms adopted by society's social and cultural institutions, which refers to custom and tradition, religious and social conventions and practices. Social institutions contribute to a culturally-embedded willingness to innovate, adopt new technologies, foster a propensity to trade, save and invest, and support a dynamic market economy in the presence of secure property rights, mechanisms to safeguard economic transactions, and pro-market policies, Opper [81]; North [82]. Imperfect institutions provide the most significant explanation for the relative poverty of nations, Eggertsson [83]. Formal and informal institutions 
are closely related, and formal institutions such as educational policy affect workforce participation, skill levels and a nation's knowledge capital, Hanushek and Woessmann [84].

A significant body of research suggests that countries with effective institutions experience greater economic and social development, foreign and local investment, and drive higher growth rates than countries with ineffective institutions, Sala-i-Martin et al. [76]; Acemoglu, Aghion and Zilibotti [80]; Acemoglu, Johnson and Robinson [77]. Conversely, the characteristics of the administration of government that most detract from an effective market economy include excessive bureaucracy in the form of long delays to register a business or obtain visas for workers, red tape and overregulation, corrupt state procurement practices, lack of accountability or transparency in government, and a non-independent or corrupt judiciary, Handoussa [85]. A detailed analysis of the literature that examines the relationship between institutions and development can be found in Jutting [86].

Effective institutions have been shown to influence the organization of production, reduce transaction and production costs, provide an enabling environment for competition and information flows, and play a central role in the way in which societies distribute the benefits and the costs of economic development, North (p. 19, [82]). Acemoglu, Johnson and Robinson [77] argue that institutions matter because they shape the incentives of key economic actors in society. Institutions can improve a nation's productivity and factor accumulation, Hall and Jones [87] and are a factor in the rate of FDI inflows, Benassy-Quere, Coupet and Mayer [88]. Ho et al. [89] studied foreign direct investment in Brazil, South Africa, Russia, India, China and Malaysia between 1977 and 2010 and found infrastructure, economic freedom, interest rates and market size were important determinants of inbound flows. Busse and Hefeker [90] show that government stability, law and order, government accountability and quality of the bureaucracy are significant determinants of FDI. State support for market-oriented institutions that encourage investment in physical and human capital, encourage capital market development and permit capital transfers generally reduce investor concerns about political risks such as state expropriation, unilateral withdrawal from long-term contracts, and the enactment of discriminatory laws, taxes and regulations. The evidence suggests that nations with effective market institutions generally invest more in infrastructure and human capital and will use these factors more efficiently to achieve a greater level of income, North [78]; Jones [91].

The relationship between institutions and infrastructure development is different between Asia Pacific countries in several respects. First, the nature of infrastructure requires that government agencies and policies also play a central role in the planning and approval of projects and particularly, the coordination of government agencies with overlapping jurisdictions. The coordination role of the state assumes greater importance with federal constitutional systems and with nations in which provincial and municipal administrations provide the greatest share of infrastructure services.

Second, infrastructure is not a stand-alone asset but a networked supply chain, the efficiency of which depends on its weakest link, Williamson [92]. For example, a new port facility will operate to the capacity permitted by the road, rail and other transport systems that service it. Investment in new services requires complimentary investment and/or upgrading of support services. For government, the challenges include sourcing the capital for basic infrastructure, long-term planning, coordination of state agencies, and integrated approval and regulatory processes.

Third, institutions are essentially sui generis and endogenously determined by the political, economic and social forces at work in each nation, Haggard [93]. Institutions that may prove effective in one country may not prove effective in another and different approaches will lead to different asset allocation decisions, Acemoglu, Johnson and Robinson [77]. There is also evidence that the role of institutions may differ over time with factor-driven economies at relatively low levels of development deriving greater foreign direct investment and infrastructure spending than countries further along the development path, Regan, Smith and Love [72].

Fourth, the capacity of government to provide the capital needed for both economic and social infrastructure is limited. Fiscal pressures, a reluctance to increase the tax burden and high levels of public debt provide impediments to greater public investment in the future, OECD [43]. In 2015, 
public capital investment in OECD countries averaged 5\% of GDP, which remains a benchmark for industrialised nations, Stevens and Schieb [94]. As mentioned earlier, there are significant differences between Asia Pacific countries with China (22.5\% GDP), Malaysia (10.5\%) and India (7.5\%) contributing more than the regional average of $6.4 \%$, PricewaterhouseCoopers [14].

Private investment has increased in recent years to around $10 \%$ of public capital spending in OECD countries and even greater levels in developing nations and is a policy option for government to increase future infrastructure spending to around 7\% of GDP. Private investment on any scale requires new complimentary institutions such as new procurement policies, governance and contract management/regulatory frameworks and agency capacity-building to develop the skills necessary for managing this type of investment.

The role of institutions is to mediate the relationship between infrastructure investment and output activity whilst providing the legal and incentive framework that encourages investment and growth, Esfahani and Ramirez [52]. Incentives and the efficiency with which infrastructure is managed over long-term incomplete contracts are drivers of national competitiveness. An additional factor is the efficiency of infrastructure management. Hulten [95] has argued that it is not the quantity of infrastructure that a government has but the efficiency with which it is used. The study compared the growth experience of East Asia and Africa and found that over one-quarter of the differential growth rates between the two regions could be attributed to the effective use of infrastructure resources. More recent research collaborates this finding, IMF [18]. A comparative analysis of high and low growth economies found that $40 \%$ of the growth differential was due to the efficiency effect making it the most important factor in differential growth performance. Warner found public investment had limited impact on long-run growth due in party to weak or circumvented project appraisal selection and management procedures, Warner [96]; Gupta [97]. Moreover, efficient institutions are necessary to manage the selection and efficient implementation of public infrastructure programs. Banerjee, Oetzel and Ranganathan [98] examined a panel of 40 developing countries between 1990 and 2000 and found that private participation in the sector is improved where the host country protects property rights and runs an efficient bureaucracy. An earlier study of 83 developing countries between 1984 and 2003 made similar findings and added political stability, law and order, internal and external conflict, corruption and ethnic tensions as factors, Busse and Hefeker [90].

Brenck et al. [99] studied countries in central and Eastern Europe that were recent additions to the European Union, and candidates for membership of the European Union and found a low level of private infrastructure investment. The explanation for this was found to be an unfavorable institutional environment. There is a view that the institutions most conducive to investment and particularly private investment are those that support a market economy such as an established capital market, satisfactory ratings in ease of doing business criteria, free movement of foreign exchange and a judicial system with low levels of corruption and speedy determination of civil matters, Nabi and Suliman [100]. Egert, Kozluk and Sutherland [71] examined the relationship between infrastructure, growth and institutions in 26 OECD countries between 1975 and 2006. The study found that policy frameworks with a robust decision-making process, rigorous investment evaluation and selection, and which encouraged market competition were most appropriate for delivering growth and attracting private investment.

Institutions also need to adapt to changes in economic development. What are appropriate institutions today may not be optimal in the future and what works in one institutional context may not work in another. Acemoglu, Aghion and Zilibotti [80] examined the dynamic properties of institutions as countries transition from factor-based economies to greater innovation and technology in which manufacturing and service industries assume a greater share of GDP. The willingness to adapt institutions to new circumstances on the path to economic development explains the rapid transformation of the high-growth economies of North and East Asia in the second half of the 20th Century, Studwell [101]. 


\section{Capital Markets and Market Development}

\subsection{Capital Markets in the Asia Pacific}

Infrastructure expenditure requires large sums of public and private equity and debt capital. In the Asia Pacific, governments will generally provide the early-stage capital to progress a project through to feasibility and business case stage of development. Financial assistance in the form of grants or concessional loans is available for low-income countries from official development assistance agencies, multilateral development banks, or under bi- and multilateral aid arrangements. Most infrastructure projects are put to market as an open tender although a project may proceed as an unsolicited bid or procured by direct negotiations with interested firms. Debt finance may be provided by government borrowings, taxation, the reallocation of budgets, or with the issue of general purpose or project specific public bonds. These may be issued directly by government or through government business enterprises. In 2015, USD75 bn was raised with syndicated loans from regional and international banks mainly for energy, transport and resources projects, PFI [13]. See Table 2. The majority of this debt was raised by contractors and multinational investor companies operating under long-term supply arrangements. While government may make an initial capital contribution or provide a subsidy to the project, sovereign credit risk and political risk protection may be provided to project lenders by multilateral investment guarantee agencies and development banks.

Table 2. Global and Regional Project Finance 2004-2008.

\begin{tabular}{cccccccccccc}
\hline USD bn & $\mathbf{2 0 0 4}$ & $\mathbf{2 0 0 5}$ & $\mathbf{2 0 0 6}$ & $\mathbf{2 0 0 7}$ & $\mathbf{2 0 0 8}$ & $\mathbf{2 0 0 9}$ & $\mathbf{2 0 1 0}$ & $\mathbf{2 0 1 1}$ & $\mathbf{2 0 1 2}$ & $\mathbf{2 0 1 3}$ & $\mathbf{2 0 1 4}$ \\
\hline Global & 145 & 166 & 210 & 247 & 250 & 147 & 228 & 214 & 199 & 204 & 260 \\
A-Pacific & 36 & 25 & 39 & 45 & 71 & 57 & 99 & 92 & 92 & 64 & 72 \\
$\%$ & 24.8 & 15.0 & 18.5 & 18.2 & 28.4 & 38.8 & 43.4 & 43.0 & 46.2 & 31.4 & 27.7 \\
\hline
\end{tabular}

Source: Project Finance International [13].

In 2015, most project finance was provided for projects in Australia, India, Taiwan, Korea, Mongolia, Japan, Philippines, Singapore, and Malaysia. Around $75 \%$ of the finance provided was sourced from the region with the leading arrangers from Taiwan (15.8\%), Japan (15.4\%), India (14.2\%), Australia (12.7\%) and Korea (5.8\%). See Table 3. The lending banks were resident in developed capital markets with less than 5\% lent from institutions outside the region, PFI (pp. 61-63, [13]). While there is capacity within the region to provide the financing resources to meet the present level of demand, the lack of depth and diversity of finance sources points to the need for capital market development in Asian countries where opportunity exists to bridge the gap between high domestic savings and entrepreneurs while reducing the outflow of Asian capital to foreign countries. Market development enables government to finance deficits by issuing bonds, improves access to capital, stimulates innovation in financial services and raises market liquidity and depth. A developed market supports monetary policy and brings benefits to regional economies by reducing concentrations of risk in the banking system and encouraging domestic consumption, ASIFMA [102].

Table 3. Sources of Asia Pacific Project Finance 2004-2015.

\begin{tabular}{cccccccccccc}
\hline & $\mathbf{2 0 0 4}$ & $\mathbf{2 0 0 5}$ & $\mathbf{2 0 0 6}$ & $\mathbf{2 0 0 7}$ & $\mathbf{2 0 0 8}$ & $\mathbf{2 0 0 9}$ & $\mathbf{2 0 1 0}$ & $\mathbf{2 0 1 1}$ & $\mathbf{2 0 1 2}$ & $\mathbf{2 0 1 3}$ & $\mathbf{2 0 1 4}$ \\
\hline 1 & US & UK & US & US & Spain & India & India & India & Aust & US & US \\
2 & UK & Spain & France & UK & US & Aust & Spain & Aust & India & Aust & Aust \\
3 & Aust & Qatar & S Arab & Aust & UK & Spain & Aust & US & US & UK & UK \\
4 & Korea & US & UK & Spain & Aust & US & US & Russia & UK & India & India \\
5 & Qatar & Italy & Spain & UAE & India & UK & UK & France & France & Korea & Brazil \\
\hline \multicolumn{8}{c}{ Source: Project Finance International [13]. }
\end{tabular}


For infrastructure projects, market development improves access to long-term loans up to $85 \%$ of project value and allows firms to manage interest rate and maturity risk associated with long-term investment in capital-intensive assets, Ray [103]; Laeven [104]. Deep and liquid markets provide better financing options for medium and larger businesses engaged in construction, engineering, manufacturing, materials processing, and professional services. A large number of infrastructure projects are delivered under consortium arrangements with opportunity for local firms to participate in asset delivery supply chains and benefit from technology transfer. Participation in consortium contracts will generally require local finance that is competitive in both its form and pricing to the finance available to foreign and regional competitor firms. Developed markets also attract foreign institutional and portfolio investors with flow-on effects that may improve capital market integration, facilitate risk sharing, and lower the cost of capital, Laeven [104].

Capital markets in the Asia Pacific possess characteristics that distinguish them from capital markets elsewhere in the world. The market is fragmented over many countries differentiated by the size and structure of economies, the quality of institutions, population, level of urbanisation, composition of intraregional and external trade, and the development of domestic debt and equity markets (See Table 4). Deep, liquid and efficient capital markets are essential to continued economic development in the region and significant reforms were adopted following the Asian financial crises of 1997 to develop local currency bond markets, partially liberalize domestic banks, float exchange rates, improve trade openness and the integration of markets by removing barriers to foreign investment and ownership, and capital controls, Park [105]; Rodriguez [106]. Central to these reforms was improved regional cooperation, building greater depth into local markets, improved governance and initiatives to standardize market transactions and reduce dependence on foreign currency debt, Gardiner et al. [107]. The region does not have a single authority such as the European Union to coordinate and harmonize regional agreements and to drive capital markets reform. Most recent reforms were the result of multilateral agreement and policy initiatives sponsored by a number of regional associations such as the Association of Southeast Asian Nations and financial institutions such as Asian Development Bank. The progress is remarkable given the economic and financial disparity between Asian states, the traditional dependence on foreign trade and a historical record of resistance to transparency, governance and shared information, ASIFMA [102].

Table 4. Capital Markets, Asia Pacific, 2014.

\begin{tabular}{cccc}
\hline GDP \% & Domestic Bank & Stock Exchange & Bond Market \\
\hline China & Credit & Capitalisation & On Issue \\
Hong Kong & 169.3 & 58.0 & 50.7 \\
Indonesia & 236.5 & 1111.40 & 66.8 \\
Korea (Rep.) & 43.5 & 47.5 & 14.5 \\
Malaysia & 162.4 & 86.0 & 125.1 \\
Philippines & 140.5 & 135.8 & 99.7 \\
PNG & 55.8 & 91.9 & 36.9 \\
Singapore & 51.0 & 97.1 & \\
Thailand & 126.3 & 244.5 & 82.9 \\
Vietnam & 168.6 & 106.3 & 70.5 \\
Emerging Asia $a$ & 113.8 & 24.7 & 22.6 \\
Emerging Asia & 114.5 & 99.1 & \\
Australia $b$ & 165.7 & 200.3 & 63.3 \\
Japan & 373.8 & 88.6 & 8.7 \\
\hline
\end{tabular}

Source: ADB Asia Bond Monitor 2014 [108], World Bank Database [109]. $a$ Excluding Hong Kong; $b$ Australian bond market $80 \%$ of issues offshore.

The major sources of capital in Asia are local and international banks, stock markets and Asian bond markets established in China, Hong Kong, Indonesia, Korea, Malaysia, The Philippines, 
Singapore, Thailand and Vietnam. In 2014, stock markets accounted for an average 98\% of GDP and domestic bank lending stood at $142.8 \%$ of GDP, World Bank [109]. The emerging East Asian local currency bond markets stood at 58.4\% of emerging East Asian GDP in June 2014 with USD7.6 th of outstanding bonds issued in China and accounting for $61.5 \%$ of the market, ADB [107]. Government issues accounted for $60 \%$ of bonds outstanding although recent data indicate a growth trend in private bonds, ADB [108]. See Table 4.

An analysis of government bond issues at 31 March 2015 shows that private bonds offered slightly longer maturities than government bonds with $30.2 \%$ having a term of $1-3$ years $(33.7 \%$ for government), $20.9 \%$ for $3-5$ years (19.8\%), 37.8\% for $5-10$ years (24.6\%), and $11.1 \%$ (21.8\%) for maturities longer than 10 years, ADB [108]. (See Table 5a). Around 49\% of private issues had maturities beyond 5 years compared with $46 \%$ for government. Around $94 \%$ of rated bonds carry investment grade credit standing, which is higher than the $75 \%$ level for corporate issues. The credit standing and liquidity of infrastructure bonds is generally more stable than with corporate bonds, Ehlers, Packer and Remolona [49]. The term structure of bonds is important for financing infrastructure investment with long term maturities necessary to match the cash flow characteristics of this asset class. See Table $5 b$. Outstanding corporate bonds in 2014 were mainly for the finance sector (54\%) and energy projects $(36.6 \%), \mathrm{ADB}[108]$.

Table 5. Asia Bond Market 2015.

\begin{tabular}{ccccc}
\hline \multicolumn{5}{c}{ (a) Government Issued Bond Maturities, Q1 2015 \% } \\
\hline & $\mathbf{1 - 3}$ Years & 3-5 Years & $\mathbf{5 - 1 0}$ Years & $\mathbf{> 1 0}$ Years \\
\hline China & 35 & 22 & 30 & 13 \\
Hong & 47 & 21 & 21 & 11 \\
Kong & 15 & 12 & 28 & 45 \\
Indonesia & 40 & 19 & 21 & 20 \\
Korea & 25 & 26 & 32 & 17 \\
Malaysia & 18 & 16 & 26 & 40 \\
Philippines & 24 & 20 & 33 & 21 \\
Singapore & 38 & 18 & 20 & 24 \\
Thailand & 61 & 24 & 10 & 5 \\
Vietnam & 303 & 178 & 221 & 196 \\
Total & 33.7 & 19.8 & 24.6 & 21.8 \\
Average &
\end{tabular}

\begin{tabular}{|c|c|c|c|c|}
\hline \multicolumn{5}{|c|}{ (b) Corporate Issued Bond Maturities Q1 $2015 \%$} \\
\hline & 1-3 Years & 3-5 Years & 5-10 Years & $>10$ Years \\
\hline China & 33 & 26 & 30 & 11 \\
\hline $\begin{array}{l}\text { Hong } \\
\text { Kong }\end{array}$ & 35 & 27 & 28 & 10 \\
\hline Indonesia & 50 & 30 & 20 & 0 \\
\hline Korea & 47 & 23 & 20 & 10 \\
\hline Malaysia & 16 & 16 & 38 & 30 \\
\hline Philippines & 16 & 26 & 50 & 8 \\
\hline Singapore & 25 & 20 & 35 & 20 \\
\hline Thailand & 35 & 20 & 34 & 11 \\
\hline Vietnam & 15 & 0 & 85 & 0 \\
\hline Total & 272 & 188 & 340 & 100 \\
\hline Average & 30.2 & 20.9 & 37.8 & 11.1 \\
\hline
\end{tabular}

A further source of finance is syndicated infrastructure lending provided by local and international banks. In 2014, a total of USD71.7 bn in transactions was raised for projects in Asia Pacific or 27.6\% of global placements in that year. Regional banks provide a large but not dominant source of project finance to the region and most lending is to the energy (38.8\%), transport $(23.8 \%)$ and oil and gas 
(21.2\%) industry sectors, PFI [13]. Most finance is provided as loans with less than $10 \%$ structured as corporate or revenue bonds.

Prior to the events of 2008, bonds accounted for an average $13.1 \%$ of project finance increasing to $24 \%$ in 2013 and 19.2\% in 2014, PFI [13]. The exit of credit insurers from the market in 2007 had a much greater effect in some sub-regions with Australia and New Zealand experiencing no infrastructure bond finance activity after 2006 following six years of dominance, Infrastructure Australia [110]. The underlying BBB credit rating of most infrastructure bonds in the absence of credit insurance or multilateral development agency support is an impediment to institutional and fund manager debt participation with this asset group. Presently, the majority of infrastructure bonds are rated investment grade compared with $41 \%$ of issues in North America and $21 \%$ in the European Community suggesting good liquidity, low credit risk and rates of default, Ehlers, Packer and Remolona [49].

Several features of the Asia Pacific project finance market since 2007-2008 are the rise in importance of regional banks and the tendency for a greater share of bank lending to be allocated to home country projects where debt is mainly priced in local currency, PFI [13]. The gap in supply created by the withdrawal of leading infrastructure lenders RBS, Credit Agricole, The Bank of Ireland, BNP Paribas and Banco Santander from the Asia-Pacific market was met by growth in regional lending and the acquisition of assets and operations of several European banks such as the Mitsui-UFJ acquisition of the assets and operations of the RBS group in 2012. In the period 2010-2014, local banks replaced European lenders as the leading providers of finance in the region, PFI [13].

Private investment over the past decade has mainly taken place in the telecommunications, energy and transport industries, which will also account for around $65 \%$ of future investment requirements in East Asia and the Pacific, Asian Development Bank and Asian Development Bank Institute [111]. Public private partnerships (PPPs) account for around 7.5\% of investment mainly for economic infrastructure. In most cases, investment in telecommunications and energy relies on user pay tariffs for their revenue and may be regulated internally and/or externally by a government regulatory agency. Investments in road and rail transport, social infrastructure and water projects derive revenue from government availability payments and/or user pay regimes. These investment characteristics, the maturity of national institutions, and the quality of macroeconomic management have a significant impact on the manner in which infrastructure is financed in the Asia Pacific (PFI [13]).

\subsection{Capital Market Development}

The Asian economic crises of 1997 and subsequent monetary policy tightening in the United States in 1999 had significant impact on Asian capital markets made vulnerable by highly regulated banks, restrictions on foreign direct investment, limited availability of local currency bond markets and the slow pace of market reform to smooth adjustment to tighter monetary conditions, Rodriguez [106]. Central to the crises of 1997 was the dependence of Asian governments on US denominated government debt and many regional governments responded by floating exchange rates, granting greater autonomy for central banks and in 2003, ASEAN + 3 members adopted the Asian Bond Market Initiative.

The rapid growth of the Asian regional economy in the two decades prior to the Asian financial crises of 1997 had a significant impact on the major regional economies with exports driving the rapid accumulation of foreign reserves and high domestic savings, Gyohten [112] (See Table 6). However, domestic capital markets in many Asian countries were not prepared for the greater levels of intraregional trade, investment and financial transactions that began to occur in the early 2000s and policies were quickly introduced to deliver improved financial flows and financial market cooperation. Local capital markets provide a destination for domestic savings, facilitate more efficient resource allocation, lower transaction costs, and raise the productivity of resources through invention, innovation and technological progress, primary factors in stimulating economic growth, Todaro and Smith [74]. 
Table 6. Gross Domestic Savings, Asia Pacific, 2007-2014.

\begin{tabular}{ccccccccc}
\hline GDP \% & $\mathbf{2 0 0 7}$ & $\mathbf{2 0 0 8}$ & $\mathbf{2 0 0 9}$ & $\mathbf{2 0 1 0}$ & $\mathbf{2 0 1 1}$ & $\mathbf{2 0 1 2}$ & $\mathbf{2 0 1 3}$ & $\mathbf{2 0 1 4}$ \\
\hline Australia & 26.2 & 26.5 & 28.1 & 26.6 & 28.2 & 28.4 & 27.3 & 26.8 \\
Brunei & 57.2 & 65.2 & 52.4 & 63.1 & 68.5 & 67.8 & 64.6 & 62.7 \\
Cambodia & 16.1 & 14.9 & 15.9 & 12.4 & 11.1 & 12.3 & 17.2 & 17.3 \\
China & 50.3 & 51.1 & 50.3 & 51.2 & 50.1 & 49.1 & 48.8 & 48.4 \\
Hong Kong & 32.1 & 31.2 & 29.7 & 29.8 & 28.0 & 26.4 & 24.6 & 24.0 \\
Indonesia & 28.1 & 31.0 & 31.7 & 35.8 & 36.5 & 35.4 & 34.3 & 34.4 \\
Japan & 24.3 & 22.8 & 19.6 & 20.7 & 19.4 & 19.0 & 18.3 & 18.1 \\
Korea (Rep.) & 33.7 & 32.9 & 33.2 & 35.2 & 34.5 & 33.8 & 34.1 & 34.5 \\
Malaysia & 43.3 & 43.8 & 38.1 & 39.3 & 38.8 & 36.5 & 34.5 & 34.3 \\
Mongolia & 38.3 & 29.1 & 27.5 & 32.1 & 36.3 & 33.5 & 30.7 & 29.4 \\
Myanmar & 14.9 & 17.4 & 15.8 & 32.7 & 37.0 & 36.6 & 33.7 & 32.8 \\
New Zealand & 24.9 & 22.5 & 22.3 & 22.6 & 22.3 & 22.1 & 24.4 & 24.1 \\
Philippines & 17.2 & 16.8 & 15.5 & 18.7 & 16.8 & 14.9 & 15.8 & 17.2 \\
Singapore & 53.9 & 51.3 & 51.2 & 54.3 & 53.7 & 52.6 & 52.2 & 52.1 \\
Taipei & 30.7 & 28.6 & 27.6 & 31.7 & 30.4 & 28.8 & 30.0 & 30.3 \\
Thailand & 33.4 & 30.6 & 30.0 & 30.9 & 28.5 & 28.9 & 30.1 & 30.7 \\
Vietnam & 26.3 & 23.5 & 25.7 & 27.4 & 27.7 & 29.6 & 28.4 & 27.9 \\
\hline
\end{tabular}

The Asian bond market is nine national markets located in China, Hong Kong, Indonesia, Korea, Malaysia, Philippines, Singapore, Thailand and Vietnam. The market's outstanding bonds in December 2015 were USD9105 bn of which USD5595 bn (61.4\%) were government bonds and USD3509 bn $(38.6 \%)$ were private, ADB [36], a greater level of private bonds than exists in high-income countries, Laeven [103]. There are considerable differences in size, tenors, yields, growth rate, the term structure and the mix of public and private bonds outstanding in each market. In aggregate, year on year growth in Asian bonds in December 2015 was 17.8\%.

While the Asian Bond Market Initiative improved the depth and financing options in Asian capital markets, the bond markets in the nine emerging Asia countries play a relatively minor role in the intermediation of domestic savings. In December 2014, bonds outstanding accounted for $57.6 \%$ of GDP, domestic bank loans $127 \%$, and stock exchange capitalisation was $200 \%$. While Asian capital markets have made progress in local currency issues in the past decade, considerable differences exist between countries with Korea's outstanding bonds in December 2014 125\% of GDP, Vietnam 22.6\% and Indonesia 14.5\%, ADB [108].

It is claimed that recent capital market reforms have not been matched with the regulatory change necessary to reduce concentrations of risk in the banking system, improve intermediation between domestic savings and the mobilization of capital, and extend currency convertibility on foreign exchange markets, ASIFMA [102]. Foreign holdings of outstanding local currency bonds stood at $38 \%$ in Indonesia, $28 \%$ in Malaysia and $17 \%$ in Thailand, nearly all of which was in government bonds. Foreign investment in the region's bond markets is largely driven by yield and the economic outlook of the host country, ADB (p. 11, [37]). While sovereign credit ratings provide a guide to foreign investors, transaction costs in the Asia Pacific remain high and progress with multilateral agreement for the harmonization of documentation and contract enforceability, common accounting and auditing standards, improved corporate governance particularly disclosure and reporting requirements, central clearing arrangements, insolvency laws, mutual recognition protocols, and common listing rules is slow. These reforms are necessary for further market integration and market development in the Asia Pacific, ASIFMA [102]. In addition to state reforms, studies also suggest that FDI is attracted to growth economies with effective institutions. Jadhav [114] studied FDI in Brazil, Russia, India, South Africa and China between 2000 and 2009 using a panel unit-root test and multiple regression analysis and found that economic factors outweighed institutional and political settings in these 
economies. Market size was the primary driver of FDI although trade openness, the rule of law and measures of public governance were statistically significant important environmental factors for FDI.

A deep and liquid bond market provides information to issuers and investors and informs policy makers through market responses to monetary policy changes. A bond market provides competition for the banking sector and offers a low-cost debt option to corporations with an investment grade credit rating. Bonds are an important option for infrastructure finance offering greater flexibility than project loans because of the scope to arrange tranches of various tenor, yield, currency and security status to meet the particular risk appetite of investors. Capital market development is important to facilitate the dispersion and management of risk, improve capital allocation, provide competition for local banks and play a role in the future economic development of Asia's emerging economies. Stock markets facilitate the pooling of funds from dispersed savings and allocating these to entrepreneurs offering the highest marginal product of capital, Bakaert and Harvey [115]. Efficient capital markets introduce market discipline (such as reporting and disclosure requirements, independent monitoring and compliance with performance covenants), generate investor information, and allow firms to better manage interest rate and maturity risk which is so important with long-term capital-intensive assets such as infrastructure, Laeven [104]. A particular challenge for Asian markets is further liberalization of foreign ownership and investment laws and achieving greater market integration within the Asia Pacific area, Park [105]. In 2014, 53\% of foreign direct investment flows to the region were intraregional. In East Asia, most movement was between China and Hong Kong and in Southeast Asia, FDI went to Indonesia, Philippines, Cambodia and Lao PDR, ADB [113].

Equity flows to the region between 2010 and 2014 were predominantly extra-regional with the vast majority of flows in all of the sub-regions sourced from the US and the European Union with around 21\% sourced in Asia, ADB (p. 31, [113]). The sources of debt inflows to the region were widely dispersed across a number of countries with the European Union (29.6\%) and intraregional Asia (22\%) and accounting for half of aggregate flow. Most debt inflows go to China and Hong Kong (59\%), Singapore (16\%), Philippines (15\%) and Indonesia (5\%), ADB (pp. 32-33, [113]). See Table 7.

Table 7. Foreign Direct Investment, Asia Pacific, 1990-2012.

\begin{tabular}{ccccccc}
\hline GDP \% & $\mathbf{1 9 9 0}$ & $\mathbf{1 9 9 5}$ & $\mathbf{2 0 0 0}$ & $\mathbf{2 0 0 5}$ & $\mathbf{2 0 1 0}$ & $\mathbf{2 0 1 2}$ \\
\hline Australia & 35.1 & 66.6 & 89.8 & 116.0 & 127.5 & 83.8 \\
China & 0.0 & 5.7 & 48.2 & 34.4 & 78.9 & 43.7 \\
Hong Kong & 108.4 & 210.0 & 363.1 & 381.9 & 472.2 & 421.9 \\
Indonesia & 7.1 & 32.9 & 16.3 & 28.5 & 47.7 & 43.2 \\
Japan & 94.1 & 68.8 & 66.7 & 103.6 & 74.6 & 61.8 \\
Korea (Rep.) & 39.0 & 32.5 & 30.6 & 80.0 & 99.5 & 96.5 \\
Malaysia & 110.4 & 250.7 & 124.7 & 126.3 & 165.8 & 156.2 \\
Mongolia & 0.0 & 1.9 & 3.2 & 1.8 & 15.2 & 10.5 \\
New Zealand & 19.4 & 50.0 & 35.9 & 37.7 & 49.4 & 45.7 \\
Philippines & 13.4 & 79.5 & 32.0 & 39.0 & 78.8 & 105.6 \\
Singapore & 88.2 & 168.4 & 159.5 & 248.5 & 156.5 & 142.8 \\
Taipei & 60.5 & 70.2 & 80.4 & 133.2 & 169.2 & 170.7 \\
Thailand & 28.0 & 84.2 & 24.0 & 70.8 & 87.1 & 104.7 \\
Vietnam & & & 0.8 & 17.6 & 21.1 \\
\hline \multicolumn{7}{c}{ Source: ADB (p. 268, [113]). }
\end{tabular}

Capital markets primarily exist to meet public and private sector demand for capital. However, continuing market development is necessary to provide the advanced financial services and risk management instruments increasingly demanded by corporations competing in globalized markets. The determinants of capital market development are well recognized in emerging economies and include the scale of the domestic economy, macroeconomic stability, institutional frameworks, economic freedom, interest rates, infrastructure, and the degree of openness to trade and foreign investment, Anyanwu [116]; Genberg [117]; Laeven [104], although the relative importance of these factors 
are different between countries, Ho et al., [89]. In particular, foreign institutional investors favor jurisdictions where regulations and trading rules permit quick settlement of trades, entry and exit without restrictions and liberalized foreign direct investment (FDI) laws. Indeed, a correlation exists between economic development and development of stock markets, public and private bond markets, with the correlation strongest between economic development and the size of the private bond market, Genberg [117]. Capital market development also induces growth in the banking sector suggesting a high level of complementarity between stock, bond, and bank lending and a positive link between capital markets and economic development in low and medium-income economies, Laeven (p. 8, [104]).

\subsection{Asian Capital Market Integration}

The Asia Pacific region maintains its position as the leader in global growth although both trade and economic growth has slowed since 2014. Part of the reason for lower growth is the downturn in traditional exports to North America, Australia and Europe, a structural readjustment away from exports and investment overseas and toward consumption and services, and the impact of a slowing market in China. Asia's income elasticity of trade has declined from around 2.69 before the events of $2007-2008$ to $1.30 \%$ in 2014, suggesting that growth in trade is less for a given increase in GDP, ADB [113]. At a time of reduced GDP growth, the data indicate the need for greater trade openness with further reduction in non-tariff trade barriers and greater trade facilitation, ADB (p. 8, [113]). Inbound FDI from within and outside the region increased by $26.3 \%$ and equity and debt flows decreased by $20.1 \%$ and $59.4 \%$ respectively in the four years to 2014, ADB [118]. See Table 8.

While global FDI has fallen in recent years, Asia accounted for $40 \%$ of the global total in 2014 most of which went to East Asia and Southeast Asia. In recent years, multinational corporations have assumed major importance in enhancing regional connectivity particularly in infrastructure with firms such as Thailand's Electricity Generation Authority making significant investment in energy infrastructure in Lao PDR, Cambodia and Myanmar. Other financial inflows were split between equity $(24 \%)$, debt (17\%) and bank lending (17\%). Asia is also investing internationally more than other regions accounting for $32 \%$ of the world total, UNCTAD [119]. Regional equity and bond investment flows were strongest in East Asia (83.2\% and $83.4 \%$ respectively) and the ASEAN +3 groups of countries (78.2\% and 80.5\%), ADB [118]; ASEAN [120].

The data confirm progress over the past decade achieving greater financial integration in the Asia Pacific through policy initiatives such as the ASEAN Comprehensive Investment Agreement in 2009, the ASEAN + 3 Chiang Mai Initiative on Multilateralization (CMIM) adopted in 2009 to strengthen the ASEAN bank prudential framework by providing a multilateral currency swap fund for member countries, and the Asian Bond Market Forum established in 2010. However, in most sub regions such as the ASEAN + 3 countries, financial integration has been driven more by market forces than multilateral agreement and structural reform is needed to the institutions exercising policy coordination and oversight, the harmonization of capital market regulation, documentation, governance and standardization of enforcement mechanisms remain an impediment, particularly in bond markets, to improved depth, liquidity and diversity in bond markets, Laeven [104]; Ng [121].

De facto impediments also provide a measure of the differences between countries using criteria such as time and cost of setting up a business, taxation expenses and transaction costs, OECD (p. 150, [31]). See Table 9. A further weakness in many countries is the limited diversity of national banking systems particularly in low-income countries and inflexible prudential and governance requirements. Impediments include low levels of foreign ownership, limited competition, institutional and infrastructure intermediation and lending, funds management and corporate advisory services and access to risk management services such as over-the-counter (OTC) derivatives. OTC derivatives trade in 2015 was USD320 tn with foreign exchange accounting for around 70\% of transactions. Asian regulators are moving toward the adoption of central clearing- houses, which can reduce counterparty risk on this group of transactions. However, there is considerable fragmentation in the market, which may affect liquidity in adverse market conditions, Gardiner [107]. 
Table 8. Growth in Intra and Inter-Regional Trade and Capital Flows, Asia Pacific 2011-2014.

\begin{tabular}{|c|c|c|c|c|}
\hline & \multicolumn{3}{|c|}{ Intra-Subnational } & \multirow{2}{*}{ Trade } \\
\hline & Equity & FDI & Bonds & \\
\hline ASEAN + 3 \& Hongkong & 17.9 & 85.6 & 13.0 & 45.5 \\
\hline East Asia & 13.6 & 58.0 & 9.0 & 35.5 \\
\hline Southeast Asia & 7.6 & 17.7 & 11.1 & 24.2 \\
\hline \multirow[t]{3}{*}{ South Asia } & 0.3 & 0.6 & 0.5 & 5.2 \\
\hline & \multicolumn{3}{|c|}{ Inter-Subnational } & \multirow{2}{*}{ Trade } \\
\hline & Equity & FDI & Bonds & \\
\hline ASEAN + 3 \& Hongkong & 4.0 & 5.1 & 6.5 & 10.7 \\
\hline East Asia & 3.1 & 7.0 & 7.6 & 18.2 \\
\hline Southeast Asia & 34.5 & 31.6 & 23.6 & 44.2 \\
\hline \multirow[t]{3}{*}{ South Asia } & 7.5 & 22.5 & 28.6 & 30.0 \\
\hline & \multicolumn{3}{|c|}{ Total Regional } & \multirow{2}{*}{ Trade } \\
\hline & Equity & FDI & Bonds & \\
\hline ASEAN + 3 \& Hongkong & 78.2 & 9.3 & 80.5 & 56.2 \\
\hline East Asia & 83.2 & 35 & 83.4 & 53.7 \\
\hline Southeast Asia & 57.9 & 50.7 & 65.2 & 68.4 \\
\hline South Asia & 7.7 & 23.1 & 29.1 & 35.2 \\
\hline \multirow[t]{3}{*}{ Asia } & 20.5 & 52.6 & 18.7 & 55.6 \\
\hline & \multicolumn{3}{|c|}{ Rest of World } & \multirow{2}{*}{ Trade } \\
\hline & Equity & FDI & Bonds & \\
\hline ASEAN + 3 \& Hongkong & 78.2 & 9.3 & 80.5 & 43.8 \\
\hline East Asia & 83.2 & 35 & 83.4 & 46.2 \\
\hline Southeast Asia & 57.9 & 50.7 & 65.2 & 46.3 \\
\hline South Asia & 92.3 & 76.9 & 70.9 & 64.8 \\
\hline
\end{tabular}

Source: Asian Development Bank [113]. ASEAN 3 is Brunei, Cambodia, Indonesia, Lao PDR, Malaysia, Philippines, Myanmar, Singapore, Thailand and Vietnam + China, Korea, and Japan. Growth in Regional Financial Flows 2010-2014.

Table 9. Indicators for Establishing and Operating a Business, Asia Pacific, 2015.

\begin{tabular}{ccccc}
\hline & WEF Index & ADB & ADB & Fraser \\
\hline & Ease of Business & Cost to Establish & Time to Establish & Index \\
\hline Australia & $\boldsymbol{a}$ & $\boldsymbol{b}$ & $\boldsymbol{c}$ & $\boldsymbol{d}$ \\
Brunei & 4.8 & 0.7 & 3 & 6.7 \\
Cambodia & $n a$ & 10.4 & 101 & 7.1 \\
China & 4.2 & 139.5 & 101 & 5.2 \\
Indonesia & 4.4 & 4.0 & 12 & 6.3 \\
Japan & 4.5 & 21.1 & 53 & 6.1 \\
Malaysia & 5.2 & 7.5 & 11 & 6.3 \\
Myanmar & 5.4 & 7.6 & 6 & 7.4 \\
Philippines & 4.7 & 176.7 & 72 & 5.0 \\
Singapore & 4.3 & 0.6 & 34 & 6.7 \\
Thailand & 4.6 & 6.7 & 3 & 7.8 \\
Vietnam & 4.2 & 7.7 & 28 & 6.3 \\
\hline
\end{tabular}

Note: $a$. World Economic Forum [122]. Scale: 7 is highest. Table 6 (p. 18). b. Key Indicators for Asia and the Pacific 2015, Table 8.6 (p. 351); GNI\%. 2014 year data. $c$. As for c. Days. d. Gwartney, Lawson and Hall, Indicator 5C [123]. Scale: 1 is lowest, 10 the highest.

A measure of relative market development for global economies is undertaken each year by a number of international institutions including the Fraser Institute and the Competitiveness Index 
published by the World Economic Forum (WEF). The WEF survey of capital market development includes indicators for the availability and affordability of financial services, access to financing via the equity market, availability of bank and other loans and venture capital, the regulation of securities exchanges and soundness of banks. Data for year 2010 and 2015 show little progress in this indicator for the region's emerging economies from an average 4.04 in 2010 to 4.10 in 2015 while the full sample averages were 4.65 for 2010 and 4.71 for 2015, WEF table 6 [122]. See Table 10.

Table 10. Capital Market Development Indicator 2015.

\begin{tabular}{ccc}
\hline & $\mathbf{2 0 1 0}$ & $\mathbf{2 0 1 5}$ \\
\hline Australia & 5.45 & 5.41 \\
China & 4.28 & 4.30 \\
Hong Kong SAR & 5.85 & 5.91 \\
Indonesia & 4.23 & 4.45 \\
Japan & 4.61 & 4.98 \\
Korea (Rep.) & 3.99 & 3.81 \\
Lao PDR & na & 3.69 \\
Malaysia & 5.34 & 5.60 \\
Mongolia & 3.07 & 3.22 \\
New Zealand & 5.23 & 5.73 \\
Philippines & 4.04 & 4.37 \\
Singapore & 5.76 & 5.84 \\
Taipei & 4.63 & 4.91 \\
Thailand & 4.43 & 4.61 \\
Vietnam & 4.21 & 3.77 \\
\hline
\end{tabular}

Source: WEF Competitiveness Report table 6 [122]. Score based on availability and affordability of financial services, financing via local equity market, access to loans, venture capital, regulation of securities exchanges and soundness of banks.

\section{Capital Market Development and Economic Growth}

A strategy of ASEAN, the Asia Pacific Economic Cooperation forum and the East Asia Forum in the past decade has been improvement in the integration of capital markets in the Asia Pacific region the focus of which has been the relaxation of foreign ownership and investment rules and greater openness for capital movements. However, as explained above, structural reform has not matched market development in many of the transitional economies in the region, the pace of regional market connectivity has been slow and significant challenges remain including the low rate of conversion of domestic savings to capital market supply, improved intermediation to raise growth in intra-regional trade, improved capital market innovation and overcoming institutional resistance to greater levels of transparency and governance, ASIFMA [102].

The importance of capital market development in the region cannot be understated. The literature identifies an association between capital market development and economic growth, Zhuang et al. [124] although as with other drivers of growth, such as public investment, there is evidence of two-way causation in the association, Robinson [125]; Acquah-Sam [126]. Research using cross-country data and advanced econometric techniques confirms that countries with efficient capital markets experience stronger growth than those that do not, King and Levine [127]; Levine [128]; Zhuang et al. [124]. However, this does not occur in isolation and the strength of the association is determined by a number of endogenous conditions of which the most important is effective institutions which have been shown to influence the organization of production, reduce transaction and production costs, provide an enabling environment for competition and information flows, and play a central role in the way in which society distributes the benefits and the costs of economic development, North (p. 19, [82]). Acemoglu, Johnson and Robinson [77] put the case that institutions determine the incentives of key economic actors in the economy. Institutions may also improve a nation's productivity and factor accumulation, Hall and Jones [87], and research shows that government 
stability, law and order, accountability and the quality of the bureaucracy are significant determinants of foreign direct investment, Busse and Hefeker [89]. Institutions also play an important role by providing prudential supervision of banks and non-bank financial institutions, Lin [129], corporations and securities regulation, accounting and audit standards, and laws dealing with insolvency and compliance with capital market trading rules, Stiglitz [130]; Zhuang et al. [124].

The association is also affected by the relative level of development of capital markets, Alfaro et al. [131]; Azman, Law and Ahmad [132]. Alfaro et al. [131] used cross-country data between 1975 and 1995 to show that countries with well-developed financial markets gain significantly from FDI providing an explanation for the high share of FDI that flows to developed economies, ADB [108]. FDI has also been shown to have a positive and statistically significant effect on economic growth in developing countries, Levine [128]; Agenor and Montiel [133]; Zhuang et al. [124]; Alfaro et al. [134]. However, capital market development is not an even process across developing countries and is affected by financial intermediary development, Beck, Levine and Laoyza [135], stock market liquidity and banking sector development, Levine and Zervos [136], and given levels of economic development, Mavrotas and Son [137].

Capital markets provide benefits for government and the private sector in emerging economies by enabling the trading, diversification and management of risk, Levine [128]; provide capital for infrastructure investment, Claessens and Feijen [138]; provide information and liquidity for investors and facilitate capital market integration, Bekaert and Harvey [115] and provide an entry point for institutional investors, Economic and Social Commission for Asia and the Pacific [139]. Well-developed capital markets may provide greater flexibility to manage debt maturity and currency risk, and provide more efficient risk allocation with downstream impacts for economic and social development. It is therefore an integral policy option for government in developing and transition stages of development as part of wider reforms designed to improve trade, economic openness, and the effectiveness of government's fiscal, monetary and exchange rate policies.

Domestic capital markets enable government to issue bonds to finance fiscal deficits, harness domestic savings, and reduce dependence on foreign borrowings carrying exchange rate risk. Long-term bonds provide a benchmark for pricing long-term debt and inform monetary policy by providing a yield curve and information to assist the conduct of monetary policy.

For government, capital market development assists macroeconomic stability by enabling government to finance deficits with local currency bond issues, by helping to bridge the gap between savings and investment, and providing instruments for management of monetary policy. Diversified capital markets may also improve the efficiency of capital allocation and facilitate greater dispersion of unsystematic risk in the economy. For local firms, capital markets provide options for the long-term finance, lower cost of capital and more options for the management of interest rate and maturity risk with long-term and capital-intensive assets such as infrastructure. For investors, local markets bring liquidity, market access, assist portfolio diversification and provide information about their investments and the market not otherwise available to private investors. Capital markets in emerging economies are an important institution and one that is positively associated with measures of economic development, Nowbutsing and Odit [140]; Laeven [104].

Capital markets also remove investor and borrower dependency on banks by introducing competition and providing alternatives for institutional investors. From an institutional perspective, market development also introduces market discipline at two levels. Firstly, reforms to improve regulation and oversight of corporations in matters of corporate reporting, disclosure, and governance. Moreover, strategies to improve connectivity between markets, countries and regions requires coordination of regional regulatory frameworks and standardization of compliance requirements such as common accounting, documentation and liability standards, listing rules, margin requirements for e-trading and centralized clearing arrangements. Secondly, project finance for infrastructure projects permits lenders to impose and enforce covenants under loan agreements such as loan security and 
debt service coverage ratios, reporting and disclosure requirements, and step-in rights in the event of breach of loan covenant by the borrower.

Laeven [104] identified a positive correlation between market development and the size of the banking sector, bond and equity markets. Market sophistication in the form of over-the-counter (OTC) interest rate and foreign exchange risk management instruments are more effective in the presence of a large bond market, financial openness and large volumes of external trade, Mihaljek and Packer [141]. Development of markets is also correlated with FDI flows which also have been shown to make a contribution to an economy's long-term growth rate, Agenor and Monteil [133]. Financial market development in the presence of trade openness is associated with technical innovation and wider use of financial derivatives for interest rate and currency risk management, Zhuang et al. [124].

Unlike other regional capital markets such as North America, Australia and New Zealand, and the European Union, as noted elsewhere, no single Asian authority is positioned to drive, coordinate and provide a road map for structural market development and greater uniformity in capital markets, suggesting the roadblocks to market development must be addressed under the regional economic, trade and financial market organizations of the region including the Association of Southeast Asian Nations (ASEAN) and the various economic and trade forums of the region including Asia Pacific Economic Cooperation, the Asia Economic Forum and the East Asia Forum.

\section{Conclusions}

The Asia Pacific region is one of the world's largest and the fastest growing regional economy in the world, a position it has held for over a decade. Adequate and efficient infrastructure is a fundamental requirement of a well-functioning and high-growth economy. Infrastructure provides the networks that facilitate trade and exchange, increase output capacity, reduce congestion, improve productivity, and lower public and private transaction costs. Forecasts by the Asian Development Bank and others suggest the region is facing an infrastructure investment gap and while private investment has helped meet the shortfall since the financial crises of 2008, government continues to plan, finance and operate most public infrastructure. Faced with the constraints of a low revenue base, high levels of national debt, and tight fiscal position, opportunities exist for national governments to make wider use of new infrastructure finance methods including asset recycling, wider use of revenue and tax-exempt bonds, and increasing private participation. This should also involve developing local capital market capacity to supply the specialized long-term finance and lender discipline that opens access to local firm participation and enables smaller projects to be financed in local currency.

A further challenge for sustainable growth is investment in economic and social infrastructure and ensuring greater regional collaboration to improve cross-border supply chains and foster growth in regional trade. Deep, liquid and efficient capital markets are considered essential to continued economic development in Asia and with appropriate intermediation pathways, can provide new sources of public infrastructure capital.

A review of the economic growth literature identifies positive and significant associations between infrastructure investment, capital market development and economic growth. Contextual factors the influence the effectiveness of these associations are the quality of a nation's institutions and both the amount and direction of foreign direct investment. A review of the literature suggests capital market development, regional integration and investment in infrastructure is an important source of growth in Asian Pacific countries. It is the objective of this review to build a case for further research work with a regional focus to better understand the strength and resilience of the relationship between infrastructure, capital markets, institutions and economic growth.

Conflicts of Interest: The author declares no conflict of interest. 


\section{References}

1. Rutherford, D. Routledge Dictionary of Economics, 2nd ed.; Taylor and Francis: London, UK, 2002.

2. Regan, M. Infrastructure, a New Asset Class in Australia; Gilberton Press: Adelaide, Australia, 2004.

3. Deole, S.S.; Gallaa, A.E. Population density, optimal infrastructure, and economic growth. In The Economics of Infrastructure Provisioning, The Changing Role of the State; Picot, A., Florio, M., Grove, N., Kranz, J., Eds.; CES Ifo Seminar Series; The MIT Press: Cambridge, MA, USA, 2015.

4. Pereira, A.M.; Andraz, J.M. On the Economic Effects of Public Infrastructure Investment: A Survey of the International Evidence; Working Paper 108; Department of Economics, College of William and Mary: Williamsburg, VA, USA, 2013.

5. Weber, B.; Alfen, H.W. Infrastructure as an Asset Class, Investment Strategies, Project Finance and PPP; John Wiley and Sons Limited: Chichester, UK, 2010.

6. Peng, H.W.; Newell, G. The significance of infrastructure in investment portfolios. In Proceedings of the Pacific Rim Real Estate Society Conference, Fremantle, Australia, 21-24 January 2007; pp. 1-26.

7. Bhattacharyay, B.N. Financing Asia's Infrastructure: Modes of Development and Integration of Asian Financial Markets; Working Paper Series No. 229; Asian Development Bank Institute: Tokyo, Japan, 2010.

8. McKinsey and Company. Infrastructure: Too Important for Business Leaders to Ignore. McKinsey Q. 2013, 2, 20-23.

9. Harrison, D. China Binges on Infrastructure as West Falls Behind. The Australian, 17 June 2016; p. 25.

10. Berlemann, M.; Wesselhoft, J.-E. Estimating Aggregate Capital Stocks Using the Perpetual Inventory Method, New Empirical Evidence for 103 Countries; Working Paper 125; Department of Economics, Helmut Schmidt University: Hamburg, Germany, 2012.

11. Australian Bureau of Statistics. National Accounts; Cat. No. 5204.0 2014-2015; Australian Bureau of Statistics: Canberra, Australia, 2015.

12. Mackenzie, H. Canada's Infrastructure Gap, Where It Came from and Why It Will Cost So Much to Close; Alternative Federal Budget Technical Paper; Canadian Centre for Policy Alternatives: Montreal, QC, Canada, 2013.

13. Project Finance International. League Tables. Thomson Reuters, London, UK. 2006. Available online: http:// www.ifre.com / ?\&m=0\&src=http:/ / www.ifre.com / hybrid.asp?typecode=68\&pubcode=1\&navcode=386 (accessed on 12 March 2016).

14. PricewaterhouseCoopers. Capital Project and Infrastructure Spending: Outlook to 2025; PricewaterhouseCoopers: London, UK, 2014.

15. Ding, D.; Lam, R.W.; Peiris, S.J. Future of Asia's Finance: How Can It Meet Challenges of Demographic Change and Infrastructure; International Monetary Fund Working Paper WP/14/126; International Monetary Fund: Washington, DC, USA, 2014.

16. Chong, S.; Poole, E. Financing Infrastructure: A Spectrum of Country Approaches; Reserve Bank of Australia: Sydney, Australia, 2013; pp. 65-76.

17. Bhattacharyay, B.N. Modes of Asian financial integration: Financing infrastructure. In Infrastructure for Asian Connectivity; Bhattacharyay, B.N., Kawai, M., Nag, R.M., Eds.; Asian Development Bank Institute and Asian Development Bank; Edward Elgar Publishing: Cheltenham, UK, 2015; p. 13.

18. International Monetary Fund. Making Public Investment More Efficient; Staff Report; International Monetary Fund: Washington, DC, USA, 2015.

19. Standard and Poor's. Global Infrastructure: How to Fill A \$500 Billion Hole; Ratings Direct; Standard and Poor's: New York, NY, USA, 2014.

20. Asian Bankers Association. Basel III and its Implications for Asian Banks. In Proceedings of the 25th ABA General Meeting and Conference, Taipei, Taiwan, 1-2 November 2010.

21. Productivity Commission. Public Infrastructure; Inquiry Report No. 71; Productivity Commission: Canberra, Australia, 2014; Volume 1.

22. Regan, M.; Love, P.E.D.; Smith, J. Infrastructure procurement: Learning from public private partnership experiences 'down under'. Environ. Plan. C Gov. Policy 2011, 29, 363-378. [CrossRef]

23. Chan, C.; Forwood, D.; Roper, H.; Sayers, C. Public Infrastructure Financing-An International Perspective; Productivity Commission Staff Working Paper; Australian Government, Productivity Commission: Melbourne, Australia, 2009. 
24. Abiad, A.; Almansour, A.; Furceri, D.; Granados, C.; Topalova, P. Is it time for an infrastructure push? The Macroeconomic Effects of Public Investment. In World Economic Outlook, Legacies, Clouds, Uncertainties; International Monetary Fund: Washington, DC, USA, 2014.

25. National Audit Office. The Financial Analysis for the London Underground PPPS; Report by the Comptroller and Auditor General, HC 54, 2000-2001 Session; National Audit Office: London, UK, 2001.

26. Megginson, W.L. The Financial Economics of Privatization; Oxford University Press: Oxford, UK; New York, NY, USA, 2005; pp. 21-26.

27. Reserve Bank of Australia. Privatisation in Australia; Reserve Bank of Australia Bulletin: Sydney, Australia, 1997.

28. Australian Government. The Asset Recycling Initiative, Helping State Unlock their Balance Sheets. 2014. Available online: http://budget.gov.au/2014-15/content/glossy/infrastructure/html/index.html (accessed on 20 October 2016).

29. Regan, M. Infrastructure, economic growth and development. In Proceedings of the Asian Development Bank Institute, Asian Development Bank and Bond University Conference, Strengthening Private Sector Participation for Infrastructure in the Pacific Region, Bond University and the Mantra Hotel, Gold Coast, Australia, 17-22 November 2009.

30. Helms, L.J. The Effect of State and Local Taxes on Economic Growth: A Time Series-Cross Section Approach. Rev. Econ. Stat. 1985, 67, 574-582. [CrossRef]

31. The Organisation for Economic Co-operation and Development (OECD). Statistics Database, Public Finance. Available online: http:/ /stats.oecd.org (accessed on 26 October 2016).

32. Martinez-Vazquez, J. Taxation in Asia; Asian Development Bank: Manila, Philippines, 2011.

33. International Monetary Fund. World Economic Outlook, Legacies, Clouds, Uncertainties; International Monetary Fund: Washington, DC, USA, 2014.

34. International Monetary Fund. Regional Economic Outlook, Asia and the Pacific; Sustaining the Momentum, Vigilance and Reforms; International Monetary Fund: Washington, DC, USA, 2014.

35. International Monetary Fund. National Economic and Financial Statistics Database; International Monetary Fund: Washington, DC, USA, 2016. Available online: http://data.imf.org/regular.aspx?key=60998121 (accessed on 23 June 2016).

36. Asian Development Bank. Asia Bond Monitor; Asian Development Bank (ADB): Manila, Philippines, 2015.

37. Asian Development Bank. Asian Economic Integration Monitor; Asian Development Bank (ADB): Manila, Philippines, 2016.

38. Agca, S.; Celasun, O. Sovereign debt and corporate borrowing costs in emerging markets. J. Int. Econ. 2012, 88, 198-208. [CrossRef]

39. Ang, A.; Bhansali, V.; Xing, Y. Taxes on Tax-Exempt Bonds. J. Finance 2010, 65, 565-601. [CrossRef]

40. Marlowe, J. Method of Sale, Price Volatility, and Borrowing Costs on New Issue Municipal Bonds; Working Paper; Department of Public Administration, University of Kansas: Lawrence, KS, USA, 2009.

41. Zen, F.; Regan, M. (Eds.) ASEAN Public Private Partnerships Guidelines; Economic Research Institute for ASEAN and East Asia: Jakarta, Indonesia, 2014.

42. Agenor, P.-R. Benefits and Costs of International Financial Integration: Theory and Facts. World Econ. 2003, 26, 1089-1118. [CrossRef]

43. The Organisation for Economic Co-operation and Development (OECD). Pooling of Institutional Investors Capital—Selected Case Studies in Unlisted Equity Infrastructure; OECD: Paris, France, 2014.

44. Preqin. Sovereign Wealth Fund Review; Preqin: New York, NY, USA, 2015.

45. The Organisation for Economic Co-operation and Development (OECD). Annual Survey of Large Pension Funds and Public Pension Reserve Funds, Report on Pension Funds' Long-Term Investments; OECD: Paris, France, 2015.

46. Inderst, G. Infrastructure Investment, Private Finance, and Institutional Investors: Asia from a Global Perspective; Asian Development Bank Institute Working Paper No. 555; Asian Development Bank Institute: Tokyo, Japan, 2016.

47. Sovereign Wealth Funds Institute. Asset Allocation Report 2013; Sovereign Wealth Funds Institute: Las Vegas, NV, USA, 2014.

48. Preqin. Special Report: Asian Infrastructure; Preqin: New York, NY, USA, 2015.

49. Ehlers, T.; Packer, F.; Remolona, E. Infrastructure and Corporate Bond Markets in Asia. In Proceedings of the Reserve Bank of Australia conference Financial Flows and Infrastructure Financing, Sydney, Australia, 20-21 March 2014. 
50. Australian Government Future Fund. Annual Report; Australian Government Future Fund: Melbourne, Australia, 2015.

51. Calderon, C.; Serven, L. Infrastructure and Economic Development in Sub Saharan Africa; Policy Research Working Paper 4712; The World Bank: Washington, DC, USA, 2008.

52. Esfahani, H.S.; Ramirez, M.T. Institutions, Infrastructure and Economic Growth. J. Dev. Econ. 2003, 70, 443-477. [CrossRef]

53. Mas, M.; Maudos, J.; Perez, F.; Uriel, E. Infrastructures and Productivity in the Spanish Regions. Reg. Stud. 1996, 30, 641-649. [CrossRef]

54. Paul, S. Effects of Public Infrastructure on Cost Structure and Productivity in the Private Sector. Econ. Rec. 2003, 79, 446-461. [CrossRef]

55. Aghion, P.; Jaravel, X. Knowledge Spillovers and Growth. Econ. J. 2015, 125, 533-573.

56. Baltagi, B.; Pinoi, N. Public Capital Stock and State Productivity Growth: Further Evidence from an Error Components Model. Empir. Econ. 1995, 20, 351-359. [CrossRef]

57. North, D.C.; Alston, L.; Eggertsson, T. (Eds.) Empirical Studies in Institutional Change; Cambridge University Press: New York, NY, USA, 1996.

58. Barwise, K.; Dick, G. Exports and Infrastructure; A Submission to the Infrastructure Taskforce, Centre for International Economics: Canberra, Australia, 2005.

59. Zhai, F. Benefits of infrastructure investment: an empirical analysis. In Infrastructure for Asian Connectivity; Bhattacharyay, B.N., Kawai, M., Nag, R.M., Eds.; Edward Elgar: Cheltenham, UK, 2012.

60. Ligthart, J. Public capital and output growth in Portugal: An empirical analysis. Eur. Rev. Econ. Finance 2002, 1, 3-30. [CrossRef]

61. Regan, M. Infrastructure and Growth. In Proceedings of the Commonwealth Secretariat and CESPAM Executive Seminar, Negotiating and Planning Successful Public Private Partnerships, Gaborone, Botswana, 26-29 March 2007.

62. Regan, M. Infrastructure for Economic Growth and Development: The Financing Gap. In Commonwealth Finance Ministers Reference Repor; Proceedings of the Finance Ministers Conference, Limassols, Cyprus, 30 September-2 October 2009; Commonwealth Secretariat: London, UK, 2009.

63. Aschauer, D. Is Public Expenditure Productive? J. Monet. Econ. 1989, 23, 177-200. [CrossRef]

64. Warner, A.M. Public Investment as an Engine of Growth; International Monetary Fund Working Paper No. 148; IMF: Washington, DC, USA, 2014.

65. Everaert, G.; Heylen, F. Public capital and long-term labour market performance in Belgium. J. Policy Model. 2004, 26, 95-112. [CrossRef]

66. Kamps, C. The dynamic effects of public capital: VAR evidence for 22 OECD countries. Int. Tax Public Finance 2005, 12, 533-558. [CrossRef]

67. Pereira, A.; Roca-Segales, O. Public capital formation and regional development in Spain. Rev. Dev. Econ. 1999, 3, 281-294. [CrossRef]

68. Ganelli, G.; Tervala, J. Value of WTO trade agreements in a New Keynesian model. J. Macroecon. 2015, 45, 347-362. [CrossRef]

69. Egert, B.; Kozluk, T.; Sutherland, D. Infrastructure Investment: Links to Growth and the Role of Public Policies; Economics Department Working Paper No. 686; The Organisation for Economic Co-operation and Development (OECD): Paris, France, 2009.

70. O'Fallon, C. Linkages between Infrastructure and Economic Growth; Report Prepared for the New Zealand Ministry of Economic Development, Pinnacle Research: Auckland, New Zealand, 2003.

71. Egert, B.; Kozluk, T.; Sutherland, D. Infrastructure and Growth: Empirical Evidence; Economics Department Working Paper 2009/26; The Organisation for Economic Co-operation and Development (OECD): Paris, France, 2009.

72. Nijkamp, P.; Poot, J. Meta-analysis of the impact of fiscal policies on long-run growth. Eur. J. Political Econ. 2004, 20, 91-124. [CrossRef]

73. Regan, M.; Love, P.E.D.; Smith, J. Benchmarking public private partnership environments: East Asian comparisons. In Proceedings of the Construction, Building and Real Estate Conference, Las Vegas, NV, USA, 10-13 September, 2012.

74. Todaro, M.P.; Smith, S.C. Economic Development, 11th ed.; Pearson: Harlow, UK, 2011. 
75. Rodrik, D.; Subramanian, A. The Primacy of Institutions. In The Development Economics Reader; Secondi, G., Ed.; Routledge: London, UK; New York, NY, USA, 2008.

76. Sala-i-Martin, X.; Bilbao-Osorio, B.; Blanke, J.; Hanouz, M.D.; Geiger, T. The Global Competitiveness Index 2011-2012: Setting the Foundations for Strong Productivity; World Economic Forum: Geneva, Switzerland, 2012.

77. Acemoglu, D.; Johnson, S.; Robinson, J.A. Institutions as the Fundamental Cause of Long-Term Growth; Working Paper 10481; National Bureau of Economic Research: Cambridge, MA, USA, 2004.

78. North, D.C. Structure and Change in Economic History; W.W. Norton and Company: New York, NY, USA, 1981.

79. Baumol, W.; Litan, R.W.; Schramm, C.J. Good Capitalism, Bad Capitalism and the Economics of Growth and Prosperity; Yale University Press: New Haven, CT, USA, 2007.

80. Acemoglu, D.; Aghion, P.; Zilibotti, F. Growth, Development, and Appropriate Versus Inappropriate Institutions, European Bank for Reconstruction and Development and the Japan-Europe Cooperation Fund. March 2006. Available online: http://www.ebrd.org/downloads/research/economics/japan/jrp1.pdf (accessed on 22 April 2014).

81. Opper, S. New institutional economics and its application on transition and developing economies. In New Institutional Economics, a Guidebook; Brousseau, E., Glachant, J.-M., Eds.; Cambridge University Press: Cambridge, UK, 2008.

82. North, D.C. Economics and third world development. In The New Institutional Economics and Third World Development; Harriss, J., Hunter, J., Lewis, C.M., Eds.; Routledge: London, UK, 1995.

83. Eggertsson, T. Imperfect Institutions, Possibilities and Limits of Reform; University of Michigan Press: Ann Arbor, MI, USA, 2005.

84. Hanushek, E.A.; Woessmann, L. The Knowledge Capital of Nations, Education and the Economics of Growth; CESifo Book Series; MIT Press: Boston, MA, USA, 2015.

85. Handoussa, H. The Role of the State: The Case for Egypt. In The New Institutional Economics and Third World Development; Harriss, J., Hunter, J., Lewis, C.M., Eds.; Routledge: London, UK; New York, NY, USA, 1995; pp. 133-154.

86. Jutting, J. Institutions and Development: A Critical Review; OECD Working Paper No. 210; OECD Development Centre: Paris, France, 2003.

87. Hall, R.E.; Jones, C.I. Why Do Some Countries Produce So Much More Output Than Others. Q. J. Econ. 1999, 114, 83-116. [CrossRef]

88. Benassy-Quere, A.; Coupet, M.; Mayer, T. Institutional Determinants of Foreign Direct Investment. World Econ. 2007, 30, 764-782. [CrossRef]

89. Ho, C.S.F.; Amir, K.; Nasaruddin, L.S.; Abidin, N.F.Z. Openness, market size and foreign direct investment. In Emerging Markets and Financial Resilience, Decoupling Growth from Turbulence; Hooy, C-W., Ali, R., Rhee, S.G., Eds.; Palgrave Macmillan: London, UK, 2013.

90. Busse, M.; Hefeker, C. Political risk, institutions and foreign direct investment. Eur. J. Polit. Econ. 2007, 23, 397-415. [CrossRef]

91. Jones, E.L. The European Miracle: Environments, Economies and Geopolitics in the History of Europe and Asia; Cambridge University Press: New York, NY, USA, 1981.

92. Williamson, F.O.E.; Brousseau, E.; Glachant, J.-M. New Institutional Economics, A Guidebook; Cambridge University Press: London, UK; New York, NY, USA, 2008.

93. Haggard, S. Institutions and Growth in East Asia. Stud. Comp. Int. Dev. 2004, 38, 53-81. [CrossRef]

94. Stevens, B.; Schieb, P.-A. Infrastructure: Mind the Gap; OECD Observer, No. 263; The Organisation for Economic Co-operation and Development (OECD): Paris, France, 2007.

95. Hulten, C.R. Infrastructure Capital and Economic Growth: How Well You Use It May Be More Important than How Much You Have; Working Paper 5847; National Bureau of Economic Research: Cambridge, MA, USA, 1996.

96. Warner, A. Public Investment as an Engine of Growth; Working Paper 14/148; International Monetary Fund: Washington, DC, USA, 2014.

97. Gupta, S.; Kangur, A.; Papageorgiou, C.; Wane, A. Efficiency-Adjusted Public Capital and Growth. World Dev. 2014, 57, 168-178. [CrossRef]

98. Banerjee, S.G.; Oetzel, J.M.; Ranganathan, R. Private Provision of Infrastructure in Emerging Markets: Do Institutions Matter? Dev. Policy Rev. 2006, 24, 175-202. [CrossRef] 
99. Brenck, A.; Beckers, T.; Heinrich, M.; von Hirschhausen, C. Public Private Partnerships in New EU Member Countries of Central and Eastern Europe: An Economic Analysis with Case Studies from the Highways Sector; EIB Papers; European Investment Bank: Luxembourg, 2005; Volume 10, pp. 82-112.

100. Nabi, M.S.; Suliman, M.O. Institutions, Banking Development, and Economic Growth. Dev. Econ. 2009, 47, 436-457. [CrossRef]

101. Studwell, J. How Asia Works, Success and Failure in the World's Most Dynamic Region; Profile Books: London, UK, 2013.

102. Asia Securities Industry and Financial Markets Association (ASIFMA). Asia's Capital Markets: Strategies for Sustained Growth; ASIFMA: Hong Kong, China, 2013.

103. Ray, S. Infrastructure Finance and Financial Sector Development; Working Paper 522; Asian Development Bank Institute: Tokyo, Japan, March 2015.

104. Laeven, L. The Development of Local Capital Markets: Rationale and Challenges; IMF Working Paper No. 234; International Monetary Fund: Washington, DC, USA, 2014.

105. Park, C.-Y. Asian Capital Market Integration: Theory and Practice; ADB Economics Working Paper Series No. 285; Asian Development Bank: Manila, Philippines, 2013.

106. Rodriguez, G. Emerging market bond markets at a time of taper: Challenge or opportunity? In Accelerating Emerging Capital Markets Development, Corporate Bond Markets; World Economic Forum: Geneva, Switzerland, 2015.

107. Gardiner, N.; Morel, P.; Tang, T.; Tsang, R.; Xu, Q. Asian Capital Markets, Fulfilling the Promise; The Boston Consulting Group, Inc.: Boston, MA, USA, 2013.

108. Asian Development Bank. Asia Bond Monitor; Asian Development Bank (ADB): Manila, Philippines, 2014.

109. World Bank. World Bank Database, 2016 Domestic Credit to Private Sector. Available online: http://data. worldbank.org/indicator/FS.AST.PRVT.GD.ZS (accessed on 30 October 2016).

110. Infrastructure Australia. Review of Infrastructure Debt Capital Market Financing; Australian Government: Canberra, Australia, 2014.

111. Asian Development Bank and Asian Development Bank Institute. Infrastructure for a Seamless Asia; Asian Development Bank Institute: Tokyo, Japan, 2009.

112. Gyohten, T. East Asian Capital Markets. Fordham Int. Law J. 1997, 21, 371-376.

113. Asian Development Bank. Asian Economic Integration Monitor; Asian Development Bank (ADB): Manila, Philippines, 2014.

114. Jadhav, P. Determinants of foreign direct investment in BRICS economies: Analysis of economic, institutional and political factors. Proc. Soc. Behav. Sci. 2010, 37, 5-14. [CrossRef]

115. Bakaert, G.; Harvey, C.R. Emerging equity market volatility. J. Financ. Econ. 1997, 43, 29-77. [CrossRef]

116. Anyanwu, J.C. Determinants of Foreign direct investment Inflows to Africa 1980-2007; Working Paper No. 136; African Development Bank: Tunis, Tunisia, 2011.

117. Genberg, H. Capital Market Development and Emergence of Institutional Investors in the Asia Pacific Region; WP/15/03; United Nations Economic and Social Commission for Asia and the Pacific 2015 (ESCAP): Bangkok, Thailand, 2015.

118. Asian Development Bank. Asian Economic Integration Report; Asian Development Bank (ADB): Manila, Philippines, 2015.

119. United Nations Conference on Trade and Development (UNCTAD). World Investment Report; UNCTAD: Genève, Switzerland, 2015.

120. Association of Southeast Asian Countries (ASEAN). ASEAN Community in Figures; Special Edition; The ASEAN Secretariat: Jakarta, Indonesia, 2014.

121. Ng, T.H. ASEAN Capital Market Integration and Lessons from the European Union. In Proceedings of the 44th IAFEI World Congress: Global Recovery Amidst Reforms, Makati Shangri-La Hotel, Makati, Philippine, 14-17 October 2014.

122. World Economic Forum. The Global Competitiveness Report 2014-15; World Economic Forum: Geneva, Switzerland, 2015.

123. Gwartney, J.; Lawson, R.; Hall, J. Economic Freedom of the World, Indicator 5C for 2013 Year; Fraser Institute: Vancouver, BC, Canada, 2015. 
124. Zhuang, J.; Gunatilake, H.; Niimi, Y.; Khan, M.W.; Jiang, Y.; Hasan, R.; Khor, N.; Lagman-Martin, A.S.; Bracew, P.; Huang, B. Financial Sector Development, Economic Growth, and Poverty Reduction; Economics Working Paper Series Number 173; Asian Development Bank: Manila, Philippines, 2009.

125. Robinson, J. The Generalisations of the General Theory. In The Rate of Interest and Other Essays; Macmillan: London, UK, 1952.

126. Acquah-Sam, E. Determinants of Capital Market Development in Ghana. Eur. Sci. J. 2016, 12, 251-270.

127. King, R.G.; Levine, R. Finance, Entrepreneurship and Growth. J. Monet. Econ. 1993, 32, 513-542. [CrossRef]

128. Levine, R. Finance and Growth: Theory and Evidence; National Bureau of Economic Research Working Paper 10766; National Bureau of Economic Research: Cambridge, MA, USA, 2004.

129. Lin, J. Walk, Don't Run, the Economist Viewed on 18th May 2009. Available online: http:/ /www.economist. com/businessfinance/economicsfocus/displaystory.cfm?story_id=13986299 (accessed on 13 August 2016).

130. Stiglitz, J.E. Capital Market Liberalization, Economic Growth, and Instability. World Dev. 2000, $28,1075-1086$. [CrossRef]

131. Alfaro, L.; Chanda, A.; Kalemli-Ozcan, S.; Sayek, S. FDI and economic growth: The role of local financial markets. J. Int. Econ. 2004, 64, 89-112. [CrossRef]

132. Azman, W.N.W.; Law, S.H.; Ahmad, A.H. FDI and economic growth: New evidence on the role of financial markets. Econ. Lett. 2010, 107, 211-213. [CrossRef]

133. Agenor, P.-R.; Montiel, P.J. Development Macroeconomics, 3rd ed.; Princeton University Press: Princeton, NJ, USA, 2008.

134. Alfaro, L.; Chanda, A.; Kalemni-Ozcan, S.; Sayek, S. Does Foreign Direct Investment Promote Growth, Exploring the Role of Financial Markets on Linkages. J. Dev. Econ. 2010, 91, 242-256. [CrossRef]

135. Beck, T.; Levine, R.; Loayza, N. Finance and the Sources of Growth. J. Financ. Econ. 2000, 58, 261-300. [CrossRef]

136. Levine, R.; Zervos, S. Stock Market Development and Long-Run Growth. World Bank Econ. Rev. 1996, 10, 323-340. [CrossRef]

137. Mavrotas, G.; Son, S. Financial sector development and growth: Re-examining the Nexus. In Transparency, Governance and Markets; Bagella, M., Becchette, L., Eds.; Elsevier: Oxford, UK, 2006.

138. Claessens, S.; Feijen, E. Financial Sector Development and the Millennium Development Goals; World Bank Working Paper 89; The World Bank: Washington, DC, USA, 2006.

139. Economic and Social Commission for Asia and the Pacific (ESCAP). Capital market development and emergence of institutional investors in the Asia-Pacific Region. In Proceedings of the Third International Conference on Financing for Development, Addis Ababa, Ethiopia, 13-16 July 2015.

140. Nowbutsing, B.M.; Odit, M.P. Stock Market Development and Economic Growth: The Case of Mauritius. Int. Bus. Econ. Res. J. 2009, 8, 77-88. [CrossRef]

141. Mihaljek, D.; Packer, F. Derivatives in Emerging Markets; Bank for International Settlements, BIS Quarterly Review; Bank for International Settlements: Basel, Switzerland, 2010.

(C) 2017 by the author; licensee MDPI, Basel, Switzerland. This article is an open access article distributed under the terms and conditions of the Creative Commons Attribution (CC BY) license (http:// creativecommons.org/licenses/by/4.0/). 